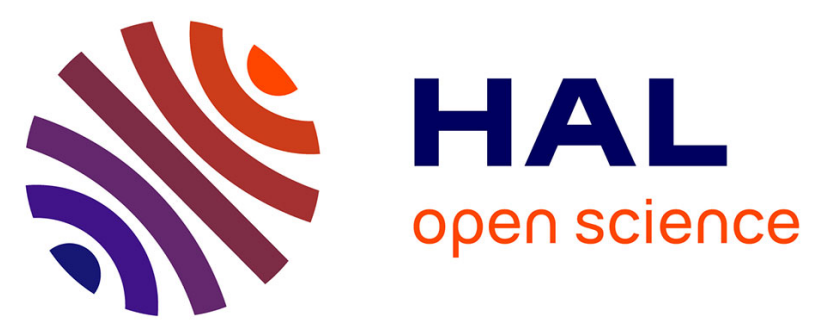

\title{
Seasonal dynamics in diatom and particulate export fluxes to the deep sea in the Australian sector of the southern Antarctic Zone
}

\author{
Andrés S. Rigual-Hernández, Thomas W. Trull, Stephen G. Bray, Ivia \\ Closset, Leanne K. Armand
}

\section{To cite this version:}

Andrés S. Rigual-Hernández, Thomas W. Trull, Stephen G. Bray, Ivia Closset, Leanne K. Armand. Seasonal dynamics in diatom and particulate export fluxes to the deep sea in the Australian sector of the southern Antarctic Zone. Journal of Marine Systems, 2015, 142, pp.62-74. 10.1016/j.jmarsys.2014.10.002 . hal-01103113

\section{HAL Id: hal-01103113 \\ https://hal.sorbonne-universite.fr/hal-01103113}

Submitted on 14 Jan 2015

HAL is a multi-disciplinary open access archive for the deposit and dissemination of scientific research documents, whether they are published or not. The documents may come from teaching and research institutions in France or abroad, or from public or private research centers.
L'archive ouverte pluridisciplinaire HAL, est destinée au dépôt et à la diffusion de documents scientifiques de niveau recherche, publiés ou non, émanant des établissements d'enseignement et de recherche français ou étrangers, des laboratoires publics ou privés. 
1 Seasonal dynamics in diatom and particulate export fluxes to the deep sea in the

2 Australian sector of the southern Antarctic Zone

3 Andrés S. Rigual-Hernandez ${ }^{1^{*}}$, Thomas W. Trull ${ }^{2,3}$, Stephen G. Bray ${ }^{2}$, Ivia Closset ${ }^{4}$,

$4 \quad$ Leanne K. Armand ${ }^{1}$.

51 Department of Biological Sciences, Macquarie University, North Ryde, NSW 2109,

6 Australia

72 Antarctic Climate and Ecosystems Cooperative Research Centre, University of

8 Tasmania, Hobart, Tasmania 7001, Australia

93 CSIRO Oceans and Atmosphere Flagship, Hobart, Tasmania 7001, Australia

104 Sorbonne Universités (UPMC, Univ Paris 06)-CNRS-IRD-MNHN, LOCEAN

11 Laboratory, 4 place Jussieu, F-75005 Paris, France

12

*Corresponding author (andres.rigualhernandez@mq.edu.au)

Keywords: diatom flux; particulate flux; sediment traps; Southern Ocean.

\section{Abstract}

Particle fluxes were recorded over a one-year period (2001-02) in the southern Antarctic

Zone in the Australian Sector of the Southern Ocean. Here, we present the results on the seasonal and vertical variability of biogenic particle and diatom valve fluxes. Total mass and diatom fluxes were highly seasonal, with maxima registered during the austral summer and minima during winter. Biogenic opal dominated sedimentation, followed by carbonate, and very low levels of organic carbon (annual average 1.4\%). The strong correlation between opal and organic carbon at both depth levels suggests that a significant fraction of organic matter exported to the deep sea was associated with 
diatom sedimentation events. Seasonal diatom fluxes appear driven principally by changes in the flux of Fragilariopsis kerguelensis. The occurrence of the sea-ice affiliated diatoms Fragilariopsis cylindrus and Fragilariopsis curta in both sediment traps is considered to correspond to the sedimentation of a diatom bloom advected from an area under the influence of sea ice. Highest fluxes of the subsurface-dwelling species Thalassiothrix antarctica registered at the end of the summer bloom were linked to a drop of the light levels during the summer-autumn transition. This study provides the first annual observation on seasonal succession of diatom species in the Australian sector of the Antarctic Zone, and corresponds, in terms of magnitude and seasonality of diatom fluxes, to those in neighbouring sectors (Pacific and eastern Atlantic).

\section{Introduction}

Diatoms are unicellular algae with an absolute requirement for silicic acid to form their frustules. They constitute a major component of phytoplankton communities, being responsible for $\sim 40 \%$ of all marine carbon fixation (Nelson et al., 1995). Diatoms are the main contributors to the silica-rich deposits in deep-sea sediments and are thought to influence the present and past global climate via their influence on the biological pump of $\mathrm{CO}_{2}$ from the atmosphere into the ocean interior (Nelson et al., 1995; Sarmiento et al., 1998; Matsumoto et al., 2002). The composition of phytoplankton communities and abundance of diatoms within them are related to specific ecological parameters of the water masses where they live (e.g., temperature, sea-ice cover and nutrient availability), and hence in the case of diatoms, their frustules can be used as biotic proxies for palaeoenvironmental and palaeoceanographic reconstructions. 
In order to evaluate the role of diatoms in the biological pump and the cycling of silicon, it is essential to thoroughly understand their ecology and the processes that the living biocoenoses undergo from their initial production in the euphotic zone to their eventual preservation in the ocean sediments (e.g. Varela et al., 2004; Grigorov et al., 2014). This knowledge is also required to validate paleorecontructions based on the diatom sedimentary record (e.g. Leventer et al., 1993; Taylor and Sjunneskog, 2002; Armand and Leventer, 2010).

The Southern Ocean is regarded as having one of the highest diatom biomasses of the global ocean. Despite its high-nutrient low chlorophyll (HNLC) regime, massive diatom blooms occur every year during spring and summer associated with specific areas, such as oceanographic fronts (e.g. Honjo et al., 2000; Moore and Abbott, 2002), coastal areas of Antarctica (e.g. Wefer et al., 1988, Bathmann et al., 1991; Arrigo et al., 1999) and the retreating sea ice edge (e.g. Smith and Nelson, 1986; Sullivan et al., 1988). As a result of this relatively high diatom productivity (Pondaven et al., 2000), large amounts of biogenic silica accumulate in the Southern Ocean sediments, mainly south of the Antarctic Polar Front (APF), where about 30\% of the global opal marine accumulation occurs (Tréguer and De la Rocha, 2013).

Moored sediment traps are one of the few available tools for monitoring particle fluxes in the open ocean over extended periods of time. They provide a means to determine the magnitude and timing of phytoplankton blooms, document species succession and estimate the remineralization of labile components throughout the water column. The use of sediment traps has contributed significantly to our understanding of diatom ecology in the Southern Ocean and coastal Antarctic systems (e.g. Leventer and Dunbar, 1987; Fischer et al., 1988; Leventer and Dunbar, 1996; Abelmann and Gersonde, 1991; Ishikawa et al., 2001; Suzuki et al., 2001; Pilskaln et al., 2004; 
74 Ichinomiya et al., 2008; Romero and Armand, 2010). However, these studies are scattered in space and time, and large regions of the Southern Ocean, including the Australian Sector, remain undocumented.

During the Australian multidisciplinary ACE CRC SAZ Project (Trull et al., 2001a), the main hydrological zones of the Australian sector of the Southern Ocean were instrumented with sediment trap mooring lines. The central goal of this experiment was to determine the origin, composition and fate of particulate matter transported to the ocean interior. This research yielded important results, including the demonstration that particulate organic carbon (POC) export in the Southern Ocean is similar to the global ocean median (Bray et al., 2000; Trull et al., 2001b).

Here, as part of the ACE CRC SAZ project, we report on the biogenic particle fluxes registered by two sediment traps deployed in the southern Antarctic Zone (60 44.43’S; $139^{\circ} \mathrm{E} 5^{3} .97^{\prime} \mathrm{S}$ ) over a year (November 2001 to September 2002) in order to (1) document the magnitude, composition and seasonal distribution patterns of the settling particle fluxes, with particular focus on diatoms and their specific composition; and (2) assess the effects of dissolution and physical processes in the water column on the diatom assemblage composition by comparing the assemblages registered by the 2000 and 3700 m sediment traps. An improved understanding of diatom ecology and changes that the diatom assemblages undergo during their sinking through the water column should lead to a better interpretation of proxy records in the Southern Ocean.

\subsection{Oceanographic setting}

The Antarctic Circumpolar Current (ACC) flows eastward around Antarctica driven by strong westerly winds connecting the Pacific, Atlantic and Indian Oceans. Several circumpolar jets or fronts divide the ACC into distinct zones (Fig. 1a), each one 
characterized by specific hydrological and biochemical properties (Orsi et al., 1995). The fronts coincide with strong current cores of the ACC defined by contours of sea surface height (SSH). Each of these fronts consists of multiple branches or filaments, where their position varies rapidly over time (Sokolov and Rintoul, 2002, 2007 and 2009a, b). From north to south, these fronts and zones are the Subtropical Front (STF), the Subantarctic Zone (SAZ), the Subantarctic Front (SAF), the Polar Frontal Zone (PFZ), the Polar Front (PF), the Antarctic Zone (AZ) and the Southern ACC Front (SACCF) (Sokolov and Rintoul, 2009a, b).

The surface waters of the Australian sector of the Southern Ocean are nitrate and phosphate rich and their concentrations remain fairly uniform across the ACC (Bostock et al., 2013). In contrast, silicic acid (Si) content shows a marked south to north gradient. Highest Si concentrations are reached south of the Polar Front Zone (up to 70 $\mu \mathrm{M}$ ), whereas the Subantarctic Zone waters exhibits low Si values (1 to $5 \mu \mathrm{M}$ ) (Coale et al., 2004; Bostock et al., 2013). Despite the relatively high macronutrient concentrations, Southern Ocean surface waters are often characterized by relatively low phytoplankton biomass. Light limitation related to deep mixing (Sakshaug and HolmHansen, 1984) and extremely low concentrations of trace metals such as iron (De Baar et al., 1995; Johnson et al., 1997; Fitzwater et al., 2000; Martin et al., 1990; Boyd et al., 2000) seem to be the main causes for this "high-nitrate, low-chlorophyll” (HNLC) regime.

Sea ice seasonality off East Antarctica is considered linked to patterns of oceanic currents, which in turn are related to sea floor topography (Massom et al., 2013). Seasonal sea-ice advance occurs from early autumn through early spring followed by retreat from late spring through summer (Comiso et al., 1984; Kimura and Wakatsuchi, 2011; Massom et al., 2013). 
124 Our study site, station $61 \mathrm{~S}\left(60^{\circ} 44.43^{\prime} \mathrm{S} ; 139^{\circ} \mathrm{E} 53.97^{\prime} \mathrm{S}\right)$, is located within the southern

125 Antarctic Zone (AZ-S; Parslow et al., 2001), between the southern branch of the PF $126\left(59^{\circ} \mathrm{S}\right)$ and the southern front of the SAACF (Rintoul and Bullister, 1999; Rintoul and

127 Sokolov, 2001). The mooring site is within the same region where the first open-ocean 128 iron enrichment experiment in the Southern Ocean (Southern Ocean Iron Release 129 Experiment - SOIREE) was conducted (Boyd et al., 2000) and can be considered representative of the region between the PF and the SACCF (between $54^{\circ} \mathrm{S}$ and $62^{\circ} \mathrm{S}$ ) 131 (Trull et al., 2001c). Despite surface waters rich in macronutrients (i.e. silicate, phosphate and nitrate), the algal biomass accumulation is considered low $(<0.5 \mu \mathrm{g} / \mathrm{L})$

(Parslow et al., 2001; Popp et al., 1999; Trull et al., 2001c). Copepods, mainly large calanoid copepodites, dominate the zooplankton community at the study site. Grazing pressure is considered low ( $<1 \%$ of the phytoplankton standing stock removed per day) and is thought not to greatly influence the development of the annual bloom (Zeldis, 2001). Very low iron concentrations (0.1-0.2 nM; Sohrin et al., 2000; Boyd et al., 2000) appear to be responsible for the low primary production. The study area is far from the influence of coastal waters and just north of the maximum winter sea-ice extent (Fig. 1b; Massom et al., 2013).

\section{MATERIAL AND METHODS}

\subsection{Field experiment}

Site $61 \mathrm{~S}$ was instrumented with a mooring line equipped with three McLane Parflux time series sediment traps (Honjo and Doherty, 1988) placed at 1000, 2000 and $3700 \mathrm{~m}$ depth in a water column of 4393m (Fig. 1c). Each trap was paired with an Aanderaa current meter and temperature sensor. The trap sampling cups were filled with a buffered solution of sodium tetraborate $\left(1 \mathrm{~g} \mathrm{~L}^{-1}\right)$, sodium chloride (5 $\left.\mathrm{g} \mathrm{L}^{-1}\right)$, strontium 
149 chloride $\left(0.22 \mathrm{~g} \mathrm{~L}^{-1}\right)$, and mercury chloride $\left(3 \mathrm{~g} \mathrm{~L}^{-1}\right)$. Cup rotation intervals were 150 synchronized between traps and were established based on anticipated mass fluxes. The 151 shortest sampling intervals were 8 days and correspond with the austral summer and 152 autumn, whereas the longest interval was 55 days corresponding with austral winter 153 (Table 1). No samples were recovered from the shallowest trap owing to equipment 154 malfunction. The two deeper traps completed their collection sequence as programmed without any instrumental failures providing a continuous time-series for 317 days (November 30, 2001 to September 29, 2002) divided into 21 collecting intervals. Owing to the low particle fluxes registered at the onset and end of the experiment insufficient material remained for diatom analysis of cup 1 of the $2000 \mathrm{~m}$ trap and cups 1, 2, 19, 20 and 21 of the $3700 \mathrm{~m}$ trap (Table 1). After recovery, sediment trap cups were removed, capped on board and stored at $4^{\circ} \mathrm{C}$ in the dark until they were processed. The original samples were sieved through a $1 \mathrm{~mm}$ nylon mesh in order to remove the largest swimmers, and only the fraction $<1 \mathrm{~mm}$ was analyzed. Then, they were split into 10 equal fractions using a McLane WSD-10 wet-sample divider. One complete split was used for microplankton analysis. A detailed description of the geochemical analytical procedures is given by Trull et al. (2001b) and Bray et al. (2000). Component fluxes are reported for individual cups along with average values over the collection or deployment period for each component (Table 1). As the collection period was shorter than a calendar year, annual mean estimates were determined and are presented in Table 1. These annual estimates take into account the fact that the unobserved days occurred 170 in winter when fluxes were low, and were obtained by using the flux for the last winter cup (\#21 in 2002) to represent mean daily fluxes during the unobserved period. calculated (Table 2). 


\subsection{Siliceous microplankton sample preparation and analysis}

176 Each diatom fraction sample was refilled with distilled water to $40 \mathrm{ml}$, from which 10

177 ml was subsampled and buffered with a solution of sodium carbonate and sodium

178 hydrogen carbonate $(\mathrm{pH} 8)$ and kept refrigerated for future calcareous nannoplankton

179 analysis. The remaining $30 \mathrm{ml}$ was treated with hydrogen peroxide, potassium

180 permanganate and concentrated hydrochloric acid in order to clean the sample of

181 organic matter and calcareous components following the methodology of Romero et al.

182 (1999, 2000). The resulting sediment slurry was stored in bottles filled with distilled

183 water. Microscopic slides were prepared following the decantation method outlined by

184 Flores and Sierro (1997). This method produces random settling of the diatoms for

185 quantitative microscopic purposes. The dried cover-slip was permanently mounted onto

186 a glass slide with Norland optical adhesive 61 mounting medium (Refractive index:

187 1.56).

188 Qualitative and quantitative analyses were performed using a Olympus BH-2 compound 189 light optical microscope at 1000x magnification with phase-contrast illumination. A minimum of 400 specimens were counted per sample. Each diatom valve was identified to the lowest taxonomic level possible. Scanning Electron Microscope observations of selected samples were used to verify taxonomic identifications made with the LM. The recommendations of Schrader and Gersonde (1978) were used as a basis for the counting of diatom valves. We did not include the counts of the girdle bands of Dactyliosolen antarcticus in the determination of relative abundances.

196 The microplankton counts were transformed into daily fluxes of specimens $\mathrm{m}^{-2} \mathrm{~d}^{-1}$ following the formula of Sancetta and Calvert (1988) and Romero et al. (2009): 


$$
F=\frac{N x\left(\frac{A}{a}\right) \times V \times S}{d x T}
$$

where " $F$ " is the daily flux of specimens, " $N$ " the number of specimens, "A" the total area of a Petri dish, "a" the analysed area, "V" the dilution volume, "S" the split of the cup, "d" the number of days of collection and "T" the aperture area of the sediment trap. the relative abundance data $\left(\mathrm{H}^{\prime}=-\sum p_{\mathrm{i}} \log _{2} p_{\mathrm{i}}\right.$, where $\mathrm{p}=\mathrm{n} 1 / \mathrm{N}, \mathrm{n} 1=$ number of specimens of one taxon and $\mathrm{N}$ the total number of specimens). Large values of $\mathrm{H}$ indicate greater diversity.

The annualized diatom valve flux for the 2000 m sediment trap was estimated following the same procedure as for the component fluxes (Table 1).

The temporal overlap of diatom fluxes between $2000 \mathrm{~m}$ and the $3700 \mathrm{~m}$ traps occurred between December-May (172 days) (Table 1). This overlap was used to estimate the sinking velocities of diatom valves and to track the alteration of settling diatom assemblages between traps. The sinking settling velocities for the main diatom taxa were calculated from the time lag between associated peaks in both traps and the vertical distance between traps. We used a squared-chord distance as the metric for assessing the similarity between the diatom assemblages of both traps (Ortiz and Mix, 1997). Squared chord distance values can range between 0.0 and 2.0, with 0.0 indicating identical proportions of species within the assemblages being compared.

\subsection{Satellite imagery, meteorological and oceanographic data}

Weekly mean sea surface temperature (SST) data for the period 2001 to 2002 was extracted from the NOAA Optimum Interpolation Sea Surface Temperature Analysis database (Reynolds et al., 2002). The monthly averages of the upper $300 \mathrm{~m}$ thermal 
structure for the 2001-2002 period (Fig. 2) were obtained for the sampling location from the World Ocean Atlas 2009 (Locarnini et al., 2010). The maximum weekly SST mean during the field experiment was $2.94{ }^{\circ} \mathrm{C}$ degrees occurring in March 2002, whereas the minimum was $0.12{ }^{\circ} \mathrm{C}$ at the beginning of October 2002. Changes of the weekly mean SST mirrored the seasonal changes in the vertical structure of the water column temperature profile. A pattern of stratification during austral summer months and vertical homogeneity in autumn and winter was noted during the field experiment (Fig. 2).

Satellite-derived monthly chlorophyll-a concentration and photosynthetically active radiation (PAR) estimates were obtained from NASA's Giovanni program (Acker and Leptoukh, 2007) (Fig. 2). The pigment concentration record was then used as a proxy for surface algal biomass accumulation. The overall chlorophyll-a levels were low $\left(0.07-0.30 \mathrm{mg} / \mathrm{m}^{3}\right)$ and similar to previous observations in the study area (Trull et al., 2001c). The increase in the algal biomass commenced in September 2001 and reached its highest levels in November 2001, coinciding with a maximum in the insolation levels (Fig. 2). Pigment concentration declined through summer and reached its lowest levels in autumn and winter (March to August 2002).

\section{RESULTS}

\subsection{Bulk composition}

Total fluxes of particulates at both traps were highly seasonal, with maxima registered during the austral summer (up to $1151 \mathrm{mg} \mathrm{m}^{-2} \mathrm{~d}^{-1}$ at $2000 \mathrm{~m}$ and $1157 \mathrm{mg} \mathrm{m}^{-2} \mathrm{~d}^{-1}$ at 3700 $\mathrm{m}$ ) and almost negligible fluxes during winter (up to $42 \mathrm{mg} \mathrm{m}^{-2} \mathrm{~d}^{-1}$ at $2000 \mathrm{~m}$ and below detection limits at $3700 \mathrm{~m}$ ) (Fig. 2). The fluxes of total particulates at 2000 and $3700 \mathrm{~m}$ depth showed similar seasonal variations and were closely correlated $\left(\mathrm{R}^{2}=0.82\right.$; Fig. 
4). Particulate fluxes were slightly higher at $2000 \mathrm{~m}\left(261 \pm \mathrm{mg} \mathrm{m}^{-2} \mathrm{~d}^{-1}=\right.$ deployment average \pm standard deviation) than at $3700 \mathrm{~m}\left(216 \pm 337 \mathrm{mg} \mathrm{m}^{-2} \mathrm{~d}^{-1}\right)$. Biogenic silica $\left(\mathrm{SiO}_{2}\right)$ was the dominant bulk component, regardless of the sampling period or depth (deployment average $=76 \%$ at 2000 and $78 \%$ at $3700 \mathrm{~m}$ ). The highest relative contribution of opal was registered from the end of summer through early-autumn at both depths (Table 1). Secondary contributors were carbonate $\left(\mathrm{CaCO}_{3}\right)(7 \%$ at $2000 \mathrm{~m}$ and $9 \%$ at $3700 \mathrm{~m})$ and particulate organic carbon (POC) $(1.4 \%$ at $2000 \mathrm{~m}$ and $1.2 \%$ at $3700 \mathrm{~m})$. The relative concentration of carbonate and POC was at its highest in austral spring and summer (Table 1). The fluxes of all components were closely correlated. The results of the correlation matrix are given in Table 2. Total mass flux showed a strong correlation with POC at both sediment traps $\left(\mathrm{R}^{2}=0.86\right.$ at $2000 \mathrm{~m}$ and $\mathrm{R}^{2}=0.87$ at 3700 m). $\mathrm{BSiO}_{2}$ fluxes were also highly correlated with POC at both depths $\left(\mathrm{R}^{2}=0.83\right)$, whereas $\mathrm{CaCO}_{3}$ and POC fluxes exhibited the lowest values $\left(\mathrm{R}^{2}=0.24\right.$ at $2000 \mathrm{~m}$ and $\mathrm{R}^{2}=0.63$ at $\left.3700 \mathrm{~m}\right)$.

The molar POC/PN ratios were relatively low (Table 1), and thus similar to surface Southern Ocean particles and phytoplankton (Copin-Montegut and Copin-Montegut, 1983).

\subsection{Composition of the biogenic opal fraction}

The biogenic opal fraction was composed of diatoms, silicoflagellates, radiolarians and the dinoflagellate Actiniscus pentasterias. Diatoms were, numerically, the dominant siliceous plankton group registered by the traps with a mean flux between $67 \times 10^{6}$ and $76 \times 10^{6}$ valves $\mathrm{m}^{-2} \mathrm{day}^{-1}$ at $2000 \mathrm{~m}$ (annualized mean and deployment average, respectively). Mean diatom flux at the $3700 \mathrm{~m}$ trap yielded higher values (deployment average $=132 \times 10^{6}$ valves $\mathrm{m}^{-2}$ day $^{-1}$ ) due to the lower sampling duration (172 days) over the winter season (Table 1). Silicoflagellates and radiolarians were three and four 
orders of magnitude lower than diatoms (not shown), whereas only one specimen of $A$. pentaserias was indentified in the lower trap. At both depth levels, total diatom fluxes showed strong seasonal variations that closely followed total mass seasonality with Pearson correlation coefficients of $r=0.88$ for $2000 \mathrm{~m}$ and $r=0.81$ for 3700 m (Fig. 4).

277 Diatom frustules from 61 taxa were identified over the entire experiment and are listed 278 in Table 3 together with their relative contribution for the whole sampling period. The seasonal changes in the diatom flux and main species at mooring site $61^{\circ} \mathrm{S}$ are plotted in Figure 5.

Diversity index values $\left(\mathrm{H}^{\prime}\right)$ followed the same seasonal trend as total diatom flux at both depths, with highest values registered during austral summer and lowest during winter (Fig. 5). The squared-chord distance between the sediment trap diatom assemblages at 2000 and $3700 \mathrm{~m}$ was 0.003 , indicating highly similar proportions of species within depths.

The dominant species of the diatom assemblage was Fragilariopsis kerguelensis with a mean flux between $53 \times 10^{6}$ and $60 \times 10^{6}$ valves $\mathrm{m}^{-2}$ day $^{-1}$ at $2000 \mathrm{~m}$ (annualized mean and deployment average, respectively). This species contribution ranged from $37 \%$ to $96 \%$ of the total assemblage at $2000 \mathrm{~m}$ (average relative contribution for the overlapping period between traps $=72 \%$; Table 3 ) and from $31 \%$ to $82 \%$ at $3700 \mathrm{~m}$ (average relative contribution for the overlapping period between traps $=68 \%$ ) $($ Table 3). The diatom flux peaks at both depths can be attributed to an increased flux of $F$. kerguelensis, with exception to a peak in late January at 2000 m when Fragilariopsis pseudonana dominated the settling assemblage (39\%). Secondary contributors to the diatom assemblage at 2000 and 3700 m were Thalassiosira lentiginosa (average relative contribution for the overlapping period between traps $=5 \%$ and $7 \%$, respectively), 
299 Fragilariopsis curta (1\% and 1\%) and Azpeitia tabularis (1\% and 1\%) (Table 3 and Fig.

300

301

302

303

304

305

306

307

5). It is worth noting that some large and/or entangled frustules of some diatom taxa, such as Thalassiothrix (Hallegraeff, 1986), could have been be retained in the $1 \mathrm{~mm}$ screen mesh, and therefore, underrepresented in this study.

Scanning electron microscope (SEM) pictures of some of the most relevant taxa are shown in Fig. 6.

\subsection{Diatom settling velocities}

The calculation of the sinking velocities of the main diatom taxa was only possible for the "particle bloom" period, i.e. from December to March, when distinct peaks were registered in both sediment traps (Fig. 5). The precision of the calculations is limited by the duration of the sampling intervals during this period (8 days). The majority of the taxa exhibited an offset of a single sampling interval (8 days) between the 2000 and $3700 \mathrm{~m}$ traps, suggesting and average settling speed of $210 \mathrm{~m} \mathrm{~d}^{-1}$.

\section{DISCUSSION}

\subsection{Quality check of downward particle fluxes}

The use of sediment traps has greatly enhanced our understanding of particle transfer in open ocean environments. However, laboratory and field experiments have shown that the measurement of downward particle fluxes can be subject to several hydrodynamic biases (e.g. Gardner, 1980; Baker et al., 1988, Yu et al., 2001). Therefore, an assessment of the trapping efficiency is needed prior to interpreting the results of any sediment trap experiment. 
322 Our mooring line at site $61^{\circ} \mathrm{S}$ was maintained taut by the distribution of floats along the

323 line and at the mooring head. Measured mean current speeds at both trap levels were

324 always lower than $10 \mathrm{~cm} \mathrm{~s}^{-1}$ that is, as a rule of thumb, considered the threshold at

325 which trapping efficiency decreases significantly (e.g. Baker et al., 1988, Honjo et al.,

326 1992, Yu et al., 2001, Heussner et al., 2006). On the basis of global comparisons, these

327 conditions suggest that fluxes registered by the traps were unlikely to be significantly

328 biased by under- or over-trapping (Honjo. 1996; Yu et al., 2001).

\subsection{Variability of total mass flux and composition of particles}

The seasonal variability of the vertical particle transfer at site $61^{\circ} \mathrm{S}$ appears principally controlled by seasonal changes in the euphotic zone productivity. A significant increase in chlorophyll-a concentration from October 2001, approximately two months before any significant warming or stratification occurs (Fig. 2), is in line with an increase in incident insolation from the beginning of spring. Taking into account that pigment concentration at the sea surface reached its highest levels during November 2001 (Fig. 2), and that maximum total particle and diatom fluxes were registered at the beginning of January 2002 (Figs 3 and 5), a time lag of about two months between peak production in the surface waters and onset of particle export in the study area can be assumed. This feature is in agreement with the observations of Buesseler et al. (2001) in the Pacific Sector of the Southern Ocean who reported a similar delay in the delivery of the surface bloom to the ocean interior. Contrastingly, algal biomass reached its annual minimum during the austral winter (June-September) (Fig. 2) and very low particle and diatom export fluxes were registered by the traps (Fig. 3 and 5). These low chlorophyll$a$ concentration and flux values appear to be driven by two factors: (i) insufficient sunlight as a result of the low solar angle and shortened day length that reduced the ability to increase biomass and (ii) intense vertical mixing that transported 
347 phytoplankton below their critical depth, i.e. depth at which the rate of photosynthesis equals the rate of respiration (Fig. 2).

In terms of particle composition, silica-rich and carbonate-poor particulate fluxes registered by the traps mirrored the dominance of diatoms in the waters south of the Antarctic Zone, south of Tasmania. The composition of the settling material is consistent with that of the surface sediments in the region. Opal content in the surface sediments of the Southern Ocean increases from north to south, being the dominant component south of the APF. In contrast, $\mathrm{CaCO}_{3}$ is dominant north of the SAF and decreases southward (Honjo et al., 2000).

Total mass and POC fluxes provided the strongest correlation at both sediment traps

(Table 2). As $\mathrm{BSiO}_{2}$ dominated the mass fluxes throughout the sampling period, changes in the $\mathrm{BSiO}_{2}$ flux directly affected POC fluxes, suggesting that diatom valve sedimentation plays an important role in controlling the organic carbon export to depth at the $\mathrm{AZ}$ site. On the other hand, the small $\mathrm{CaCO}_{3}$ fluxes and lower correlation values with POC at both sediment traps suggest that $\mathrm{CaCO}_{3}$ had a lesser influence on the POC remains unknown.

\subsection{Seasonal trend of diatom fluxes and species composition}

367 The annual diatom fluxes registered by the 2000 m sediment trap (Table 1) fall within the range of those estimated by Fischer et al. (2002) in the AZ of the eastern Atlantic (20 x $10^{6}$ valves $\mathrm{m}^{-2} \mathrm{~d}^{-1}$ ) and those reported by Grigorov et al. (2014) in the Ross Sea Gyre $\left(93 \times 10^{6}\right.$ valves $\left.\mathrm{m}^{-2} \mathrm{day}^{-1}\right)$. The diatom fluxes recorded at site $61^{\circ} \mathrm{S}$ are therefore 
371 comparable in magnitude to previously reported diatom data sets of the $\mathrm{AZ}$ in the 372 Southern Ocean.

373 Although several factors, such as grazing, dissolution and lateral advection, can 374 influence diatom flux (Boltovskoy et al. 1993), the similar seasonal patterns, with a two 375 month offset between primary productivity and diatom flux variations (Figs. 2 and 5a) 376 suggest that the primary signal of the phytoplankton bloom in the overlying water masses is registered by the traps. About two-thirds of the annual diatom export fluxes at each trap depth were registered during January and February (Fig. 5). A markedly seasonal pattern is characteristic of high latitude systems (e.g. Wefer et al., 1988; Dunbar et al., 1998; Honjo et al., 2000; Fischer et al., 2002; Pilskaln et al., 2004; Romero and Armand, 2010) and illustrates the opportunistic character (r selection) of the dominant species during the summer bloom. As a consequence of this rapid diatom biomass increase, silica in the AZ-S is often stripped out the mixed layer by midsummer (Trull et al., 2001c).

The temporal variations in the composition of diatom assemblages mirrored the changes of the hydrographic conditions in the AZ-S, south of Tasmania. Overall, the major diatom taxa recorded at our mooring site are typical of living and fossil assemblages representing open ocean waters of the Antarctic Zone (Romero and Armand, 2010; Crosta et al., 2005, respectively).

The seasonal diatom flux was mainly driven by changes in the flux of the large, heavilyal., 2006). Large abundances of F. kerguelensis in phytoplankton blooms have also been previously reported in our study area during the SOIREE experiment (Gall et al., 2001; Trull and Armand, 2001), in the AZ of the south-west Atlantic (Hart, 1934) and in the 
vicinity of open-ocean fronts in the Atlantic and Pacific sectors (Bathmann et al., 1997;

397 Laubscher et al., 1993; Grigorov et al., 2014). The relative contribution of $F$. kerguelensis at both $61 \mathrm{~S}$ traps (68-80\%; Table 1) is consistent with its distribution in the Southern Ocean surface sediments where its maximum abundances (70-83\%) are found between the Polar Front and the maximum summer sea-ice edge (Crosta et al., 2005). Fischer et al. (2002) and Grigorov et al. (2014) reported lower relative abundance and fluxes of this species in sediment traps in the AZ of the Atlantic sector (29\%; 6 × $10^{6}$ valves $\left.\mathrm{m}^{-2} \mathrm{~d}^{-1}\right)$ and in the Ross Sea Gyre (22\%; $20 \times 10^{6}$ valves $\left.\mathrm{m}^{-2} \mathrm{~d}^{-1}\right)$, respectively. However, these sites were under the influence of seasonal ice, where seaice affiliated taxa such as smaller Fragilariopsis species and Chacetoceros spp., are known to often dominate the diatom assemblages (Armand et al., 2005).

At the onset of the summer particle "bloom”, $\mathrm{H}^{\prime}$ rises significantly due to the burst of reproduction and sedimentation of most of the diatom taxa (Fig. 5a). The small and rapidly dividing diatoms Chaetoceros group, Fragilariopsis pseudonana, Fragilariopsis rhombica, Fragilariopsis separanda and Pseudo-nitzschia spp., together with the cool open ocean species Thalassiosira gracilis, are major contributors to the bulk of the spring-summer maximum (Fig. 5). The majority of these diatoms correspond to the Group 1 defined by Quéguiner (2013), consisting of slightly silicified and fast-growing species that undergo rapid species succession during productive periods. The biomass accumulation of such diatoms is thought to be controlled principally by nutrient availability rather than grazing pressure. This concept agrees well with the observations

417 of Zeldis (2001) who reported low grazing impact over the bloom development during the SOIREE experiment. At the end of their growth season, these bloom-forming species are considered to undergo mass mortality resulting in the formation of aggregates that rapidly sink from the euphotic zone (Assmy et al., 2013). 
421 The AZ-S site is remote from the direct influence of sea-ice in summer (Massom et al.,

422 2013; Fig. 1b), which makes the occurrence of the sea-ice affiliated diatoms 423 Fragilariopsis cylindrus and Fragilariopsis curta during January (Fig. 5b) puzzling.

424 The distribution of F. cylindrus in the modern Southern Ocean is constrained to the 425 north by the maximum summer sea ice edge (Semina, 2003; Armand et al., 2005; Esper 426 et al. 2010), whereas F. cylindrus appears limited by the maximum extension of sea ice 427 during winter (Armand et al., 2005; Esper et al., 2010). Likely explanations for the presence of these species at site $61^{\circ} \mathrm{S}$ are either (i) the occurrence of an iceberg in the vicinity of our study area or (ii) the advection of a transient bloom produced in a region under the influence of sea ice. Rich sea-ice affiliated diatom communities have been found in association with free-drifting icebergs (e.g. Smith et al., 2011), however this explanation is unlikely since our site is remote from any known iceberg pathway (Gladstone et al., 2001). Taking into account a time lag of about two months between peak production and particle export, a healthy and neutrally buoyant bloom could cover a much larger distance than that estimated for a sinking particle (detailed in 4.5). Sea-ice coverage west of $\sim 90^{\circ} \mathrm{E}$ can reach latitudes well above $61^{\circ} \mathrm{S}$ (Massom et al., 2013; Fig. 1b). We hypothesize that the pulses of F. curta and F. cylindrus could correspond to the sedimentation of a diatom bloom that was either advected from an area upstream the ACC under the influence of seasonal sea ice or transported northward by Antarctic Surface Water currents (AASW) produced by the seasonal retreat of the sea ice, south of our study.

442 Enhanced fluxes of the large and thick-walled F. kerguelensis persisted for a longer 443 period (until April) than those of Group 1 (sensu Quéguiner, 2013) most likely contributing to the progressive reduction of silicic acid concentrations in the mixed layer throughout the summer. A similar pattern was reported by Assmy et al. (2013) 
both inside and outside the iron-fertilized bloom during the European Iron Fertilization

447 Experiment (EIFEX). Fragilariopsis kerguelensis is considered a "sinking-silica 448 species” (Assmy et al., 2013) largely responsible for the decoupling of silicon and carbon cycles in the iron-limited ACC.

At the end of the diatom export maximum (i.e. February-March), Thalassiothrix antarctica contributed more significantly to the flux via increased abundances (Fig. 5b). This species is a large, slow-growing diatom distributed within discrete layers of the water column (Kemp et al., 2000). Such diatoms are considered k-strategists (Kemp and Villareal, 2013) and fall within Group 2 defined by Quéguiner (2013). High abundances of Thalassiothrix antarctica have been reported within and south of the APF (Laubscher et al., 1995; Bracher et al., 1999) and associated to a subsurface chlorophyll maximum in the PFZ south of Tasmania (Kopczynska et al., 2001; Parslow et al., 2001; Gomi et al., 2010) and in Prydz Bay (Quilty et al., 1985). We suspect that Thalassiothrix antarctica develops in parallel to Group 1 diatoms, as a result of them inhabiting the pycnocline discontinuity, exploiting deep nutrients and undergoing low rates of primary productivity under low-light conditions (Kemp et al., 2000, 2006; Quéguiner, 2013). The abrupt drop of the photosynthetically active radiation levels to less than half their peak values from February to March (Fig. 2a) and/or the occurrence of a vertical mixing event may have produced both light and/or nutrient limitation leading to the rapid flocculation and sinking of T. antarctica during the summer-autumn transition. Post-March diatom export decreases significantly (Fig. 5a) due to the reduction to 467 lowest levels of light and the concomitant intensification of mixing of the water column 468 (Fig. 2a,b). The "post-bloom" diatom assemblage is characterized by low diversity values (Fig. 5a) mainly due to the high relative abundance of F. kerguelensis (up to 96\% in September). The remaining assemblage is subsequently composed of large and 
471 heavily silicified centrics such as Thalassiosira lentiginosa, Azpeitia tabularis and

472 Thalassiosira oliveriana. These are typical open ocean diatoms (Crosta et al., 2005;

473 Romero et al., 2005) with presumed lower nutrient requirements than the summer

474 bloom-forming species.

475

\section{$476 \quad 4.4$ Transfer to depth}

477 Our results suggest that a fast and relatively undisturbed downward transport of 478 particles occurred between 2000 and 3700 m (Fig. 3 and 4). The similar BSi and POC content in both traps (Table 1) indicates that little silica dissolution and remineralization occurred between 2000 and $3700 \mathrm{~m}$. Such a result is consistent with previous sediment trap studies that reported minimal alteration of the silica and organic carbon fluxes below the mesopelagic-bathypelagic boundary ( 2000 m) (Takahashi, 1986; Honjo et al., 2009). However, the high $\mathrm{Si} / \mathrm{C}$ at both depth levels also implies that organic matter is recycled faster than opal before reaching the traps, and this must occur at mesopelagic depths. We interpret this as the remineralization of the settling material by the microbial community and by the zooplankton that preferentially feed on organic matter (Honjo, 2009). High Si/C ratios are characteristic of the iron-limited systems of the Southern Ocean where large and highly silicified species (e.g. Fragilariopsis kerguelensis) dominate the diatom assemblages. In this regard, the average POC content (1.4\%) of our samples at $2000 \mathrm{~m}$ is very low, and the average BSi/POC molar ratio for the entire collection period was less than 0.1 for both traps, in comparison to an average of $\sim 1$ for 492 a compilation of deep Southern Ocean traps (Honjo et al., 2008) and a median of 2 for a global compilation (Lampitt and Antia, 1998). This makes it clear that the trap samples have experienced very strong losses of organic carbon, consistent with previous 
studies suggesting that Southern Ocean waters south of the Polar Front can be described as low carbon export regimes (Lam and Bishop, 2007).

The sinking velocities of the major diatom taxa during the "particle bloom" indicate rapid sedimentation of the diatom assemblages between the upper and lower traps (210 $\mathrm{m} \mathrm{d}^{-1}$ ). These settling speeds are very similar to those estimated by Honjo et al. (2000) in the AZ of the Pacific Sector and are equal, or greater than, those observed in high productivity areas at lower latitudes (Honjo, 1996). In contrast, based on the time delay between samples with similar silicon isotopic signatures at different depths at site $61 \mathrm{~S}$, Closet et al. (unpublished results) estimated the settling velocities outside the production period to be $120 \mathrm{~m} \mathrm{~d}^{-1}$ or less. These observations suggests that sinking rates of diatom valves at site $61 \mathrm{~S}$ are related to flux size, perhaps because higher fluxes lead to the formation of fast-sinking aggregates (e.g. Alldredge and Gotschalkt, 1989). This concept is consistent with the observations of Grigorov et al. (2014) on sediment trap material from the Pacific Sector of the Southern Ocean who reported abundant diatom aggregates at times of peak flux and mainly individual cells and small chains outside the production period. Moreover, the formation of aggregates would also explain the enhanced POC export (Table 1) in association with high fluxes of Group 1 diatoms during the production period (Assmy et al., 2013).

The pulse of Thalassiothrix antarctica in early March at both depths coincides with an upturn of the POC fluxes (Table 1). Thalassiothrix antarctica cells are about 60 times larger (in estimated biovolume) than F. kerguelensis (Cornet-Barthaux et al., 2007), and therefore, have the potential to contribute significantly to the annual organic carbon export even at background concentrations (Goldman 1993; Goldman and McGillicuddy, 2003; Quéguiner et al., 2013). 
519 During winter, the lower sinking rates and high area/volume ratios of single diatom

520 cells may facilitate the recycling of the valves and remineralization of organic matter in

521 the upper water column. The enrichment of dissolution-resistant diatoms (e.g.

522 Fragilariopsis kerguelensis, Thalassiosira oliveriana, Azpeitia tabularis) during the

523 winter months observed in our traps could, therefore, be partially related to enhanced,

524 selective dissolution of more lightly silicified species (e.g. Pseudo-nitzschia spp.,

525 Fragilariopsis pseudonana, Chaetoceros spp.).

526 With regard to the comparison of the annual diatom assemblage between traps, their

527 highly similar abundance proportions, as revealed by the low squared chord distance

528 score, indicate that both traps registered diatom assemblages from the same source.

529 Moreover, the latter results further support the idea that silica BSi dissolution below

$5302000 \mathrm{~m}$ is minimal at the AZ-S site.

531

\section{CONCLUSIONS}

533 The main objective of our study was to document the variability in the magnitude, 534 timing and composition of particle and diatom export fluxes to the deep sea in the 535 southern Antarctic Zone (AZ-S) within the Australian sector of the Southern Ocean. To 536 examine this issue, we studied the year-round dynamics of particle flux from November 5372001 through September 2002. The overall fluxes of biogenic particles to the mid- and 538 deep water column in the AZ-S were markedly seasonal with peak fluxes occurring 539 during the austral summer and very low export during winter. This seasonal pattern is 540 mediated by algal productivity. Comparison of satellite and particle flux data suggests a 541 delay of about two months between peak production and onset of particle export. The 542 biogenic opal fraction largely dominates the export throughout the year, and is mainly delivered by diatoms. Carbonate and organic carbon are secondary components. 
544 Diatom seasonal fluxes followed the seasonality of the biogeochemical particle fluxes at

545 both depths and their magnitude (67-76 x $10^{6}$ valves $\mathrm{m}^{-2}$ day $^{-1}$ ) is similar to previously

546 published data recorded in the AZ of other sectors of the Southern Ocean. The diatom

547 assemblages recovered at our mooring site are typical of the open ocean waters of the

548 Antarctic Zone (Crosta et al., 2005) and their seasonal succession agrees well with the

549 conceptual scheme proposed by Quéguiner (2013) for the POOZ (Permanently Open

550 Ocean Zone) and the PFZ (Polar Frontal Zone). Fragilariopsis kerguelensis is, by far,

551 the most dominant diatom species in the sediment trap samples. The occurrence of the

552 sea-ice affiliated species F. cylindrus and F. curta may correspond to the sedimentation

553 of a diatom bloom advected from an area under the influence of sea ice upstream the

554 ACC. The sedimentation pulse of the deep-dwelling species Thalassiothrix antarctica

555 during the February-March transition appears to have been triggered by an abrupt drop

556 of the light levels and/or a vertical mixing event.

557 Finally, the good correlation between the total mass fluxes at both sediment traps and

558 their similar diatom species composition suggests fast and undisturbed settling of 559 particles through the deep water column at the AZ-S site.

560

561 Acknowledgements

562 This project is supported through funding from the Australian Government's Australian 563 Antarctic Science Grant Program (Project number 4078) and Macquarie University. The 564 SAZ Project is grateful for logistical and equipment support from ANARE and the 565 Australian Antarctic Division (T. Trull, ASAC grants 1156 and 2256), the CSIRO 566 Division of Marine Research Oceans and Climate Program, Geosciences Australia, and 567 New Zealand's National Institute of Water and Atmospheric Research (NIWA). The 568 officers, crews, and scientific staff of the Aurora Australis voyages are thanked for their 
569

570

571

572

573

574

575

576

577

578

579

580

581

582

583

584

585

586

587

588

589

590

591

592

593

professionalism and dedication. Anne-Marie Ballegeer is greatly acknowledged for her comments during the preparation of the manuscript. The authors acknowledge the assistance and support of Nicole Vella and Debra Birch from the Macquarie University Microscopy Unit for performing scanning electron microscopy experiments. Robert O'Malley provided remote sensing support during analysis. The chlorophyll- $a$ data used in this paper were produced with the Giovanni online data system, developed and maintained by the NASA GES DISC. Dr Anne-Marie Ballegeer is acknowledged for her suggestions and technical support. Critical comments and suggestions from two anonymous reviewers helped to improve the manuscript.

\section{FIGURE CAPTIONS}

Figure 1. a. Location of the sediment trap mooring line in the Antarctic Zone of the Australian sector of the Southern Ocean. Fronts (STF - Subtropical Front, SAF Subantarctic Front, PF - Polar Front, SB - Southern Boundary), regions (STZ Subtropical Zone, SAZ - Subantarctic Zone, PFZ - Polar Front Zone, ACC - Antarctic Zone and SACCZ - Zone south of the ACC) and maximum extension of winter sea ice (Max WSI) are shown. Triangle represents the position of $61^{\circ} \mathrm{S}$ mooring during the experiment (Nov. 2001 - Sep. 2002). b. Mean sea ice season duration map for the East Antarctic sector (1979/80-2009/10), with contours for 100, 200 and 300 days marked (modified from Massom et al., 2013). c. Schematic diagram of the Australian sector of the Southern Ocean depicting the bathymetry, main water masses and mooring configuration. SAMW - Subantarctic Mode Water, AAIW - Antarctic Intermediate Water, UCDW - Upper Circumpolar Deep Water, LCDW - Lower Circumpolar Deep Water and AABW - Antarctic Bottom Water. Figure is adapted from Bostock et al. (2013). 
595 Figure 2: (a) Monthly mean chlorophyll-a concentration (mg $\mathrm{m}^{-3}$ ), sea surface 596 temperature (SST) $\left({ }^{\circ} \mathrm{C}\right.$ ) and photosynthetically active radiation (Einstein $\mathrm{m}^{-2} \mathrm{~d}^{-1}$ ) for the 597 period November 2001 to September 2002. No data was available from April to August 598 in 2001 and 2002. (b) Seasonal variation in the vertical structure of temperature $\left({ }^{\circ} \mathrm{C}\right)$ at 599 the $61^{\circ} \mathrm{S}$ site.

600

601

Figure 3. Temporal variability of the total mass and major biogenic fluxes for $<1 \mathrm{~mm}$ 602 fraction at 2000 and 3700 m water depth from November 2001 through to November 603 2002 at the $61^{\circ} \mathrm{S}$ site.

604

605

Figure 4. Correlation between (a) mass flux ( $\mathrm{mg} \mathrm{m}^{-2}$ day $^{-1}$ ) at 2000 and $3700 \mathrm{~m}$, and (b) 606 mass flux (mg m ${ }^{-2}$ day $\left.^{-1}\right)$ and diatom valve flux $\left(10^{6} \mathrm{~m}^{-2}\right.$ day $\left.^{-1}\right)$ at 2000 and $3700 \mathrm{~m}$.

607

608

Figure 5. Seasonal variation of (a) total diatom flux and Shannon's diversity index $\left(\mathrm{H}^{\prime}\right)$ 609 and (b) flux and relative abundance of the main diatom species at 2000 and $3700 \mathrm{~m}$ sediment traps. The arrows indicate the associated peaks of valve flux at both depths used to calculate the sinking velocities.

612

613 Figure 6: SEM photos of some of the most relevant diatom taxa collected by the 614 sediment traps at site $61^{\circ} \mathrm{S}$. (a) Azpeitia tabularis. (b) Chaetoceros atlanticus (resting 615 stage). (c) Fragilariopsis curta. (d) Fragilariopsis cylindrus. (e) Fragilariopsis 616 kerguelensis. (f) Fragilariopsis pseudonana. (g) Fragilariopsis rhombica. (h) 617 Fragilariopsis separanda. (i) Pseudo-nitzschia spp. (j) Thalassiosira gracilis var. 
gracilis. (k) Thalassiosira lentiginosa. (l) Thalassiothrix antarctica. Scale bars: d, $\mathrm{f}=1$

$619 \mu \mathrm{m} ; \mathrm{h}, \mathrm{i}=2 \mu \mathrm{m} ; \mathrm{c}, \mathrm{e}, \mathrm{j}=5 \mu \mathrm{m} ; \mathrm{a}, \mathrm{b}, \mathrm{g}, \mathrm{k}, \mathrm{l}=10 \mu \mathrm{m}$.

620

621 Table 1: Daily export fluxes of total mass flux, biogenic silica $\left(\mathrm{BSiO}_{2}\right)$, calcium 622 carbonate $\left(\mathrm{CaCO}_{3}\right)$, particulate organic carbon (POC) and diatom valves registered at 623 the $61^{\circ} \mathrm{S}$ site from November 2001 through October 2002. Mass fluxes listed as zero 624 were too small to measure ( $<1 \mathrm{mg}) . *$ Average diatom fluxes for the 2000 and $3700 \mathrm{~m}$ 625 traps have been estimated for different sampling intervals (309 and 172 days, respectively).

627

Table 2: Correlation matrix $\left(\mathrm{R}^{2}\right)$ for the total mass and bulk compound fluxes at both 629 sediment traps.

630

631

Table 3: Integrated fractional abundances of the diatom taxa found at the 2000 and 632 $3700 \mathrm{~m}$ sediment traps at station $61^{\circ} \mathrm{S}$.

633

634

\section{REFERENCES}

635

Abelmann, A., Gersonde, R. (1991) Biosiliceous particle flux in the Southern Ocean, 636 Mar. Chem., 35, 503-536.

637

638 Abelmann, A., Gersonde, R., Cortese, G., et al. (2006) Extensive phytoplankton blooms 639 in the Atlantic Sector of the glacial Southern Ocean, Paleoceanography, 21, PA1013

640

641 Acker, J.G. and Leptoukh, G. (2007) Online analysis enhances use of NASA Earth 642 science data. Eos, Transactions. AGU, 88, 14-17. 
644 Alldredge, A.L., Gotschalkt, C.C. (1989) Direct observations of the mass flocculation of 645 diatom blooms: characteristics, settling velocities and formation of diatom aggregates. 646 Deep-Sea Res. (1 Oceanogr. Res. Pap.), 36 (2), 159-17

647

648 Arrigo, K.R., Robinson, D.H., Worthen, D.L., et al. (1999) Phytoplankton community 649 structure and the drawdown of nutrients and $\mathrm{CO}_{2}$ in the Southern Ocean. Science 283, $650 \quad 365-367$.

651

652 Armand, L.K., Crosta, X., Romero, O.E. et al. (2005) The biogeography of major diatom 653 taxa in Southern Ocean surface sediments: 1. Sea ice related species. Paleogeogr., 654 Palaeoclimatol., Palaeoecol., 223, 93-126.

655

656 Armand, L.K., Leventer, A. (2010) Palaeo sea ice distribution and reconstruction derived from the 657 geological record. In Sea Ice, (Eds. D. N. Thomas \& G.S. Dieckmann, G.S.), pp. 469-530, 658 Wiley-Blackwell Publishing Ltd, Oxford.

659

660 Assmy, P., Smetacek, V., Montresor, M. (2013) Thick-shelled, grazer-protected diatoms 661 decouple ocean carbon and silicon cycles in the iron-limited Antarctic Circumpolar 662 Current. PNAS 110 (51) 20633-20638.

663

664 Baker, E.T., Milburn, H.B., Tennant, D.A. (1988) Field assessment of sediment trap 665 efficiency under varying flow conditions. J. Mar. Res. 46, 573-592.

666

667 Bathmann, U., Fischer, G., Müller, P.J. et al. (1991) Short-term variations in particulate 668 matter sedimentation off Kapp Norvegia, Weddell Sea, Antarctica: relation to water 
669

670

671

672 Boltovskoy, D., Alder, V.A., Abelmann, A. (1993) Annual flux of Radiolaria and other 673 shelled plankters in the eastern equatorial Atlantic at $853 \mathrm{~m}$ : seasonal variations and 674 polycystine species-specific responses. Deep-Sea Res. (1 Oceanogr. Res. Pap.), 40(9), $675 \quad 1863-1895$.

676

677 Bostock, H.C., Barrows, T.T., Carter, L. et al. (2013) A review of the Australian-New 678 679 680

681 Boyd, P., Watson, J., Law, C.S. et al. (2000) Phytoplankton bloom upon mesoscale iron 682 683 684 685 686 687 688 689 690 691

692 Buesseler, K.O., L. Ball, J. Andrews, et al., (2001) Upper ocean export of particulate 693

Zealand sector of the Southern Ocean over the last 30 ka (Aus-INTIMATE project). Quat. Sci. Rev. 74, 35-57. fertilisation of polar Southern Ocean waters. Nature 407, 695-702.

Bracher, A.U., Kroon, B.M.A., Lucas, M.I. (1999) Primary production, physiological state and composition of phytoplankton in the Atlantic Sector of the Southern Ocean. Mar. Ecol. Pro. Ser. 190, 1-16.

Bray, S., Trull, T.W., Manganini, S. (2000) SAZ Project Moored Sediment Traps: Results of the 1997-1998 Deployments, 128 pp, Antarct. Coop. Res. Cent., Hobart, Tasmania, Australia.

organic carbon and biogenic silica in the Southern Ocean along $170^{\circ} \mathrm{W}$. Deep-Sea Res. 
695

696 Coale, K.H., Johnson, K.S., Chavez, F.P., et al. (2004) Southern Ocean iron enrichment 697 experiment: Carbon cycling in high- and low-Si waters. Science 304 (5669), 408-414. 698

699 Comiso, J.C., Zwally, H.J. (1984) Concentration gradients and growth/decay 700 characteristics of the seasonal sea ice cover. J. Geophys. Res. 89, 8081-8103.

701

702 Copin-Montegut, C., Copin-Montegut, G. (1983) Stoichiometry of carbon, nitrogen, and 703 phosphorus in marine particulate matter. Deep-Sea Res. (1 Oceanogr. Res. Pap.), 30 (1), $704 \quad 31-46$.

705

706 Cornet-Barthaux, V., Armand, L.K., Quéguiner, B. (2007) Biovolume and biomass 707 measurements of key Southern Ocean diatoms. Aquat. Microb. Ecol. 48 (3), 295-308.

708

709 Crosta, X., Romero, O., Armand, L.K., et al. (2005) The biogeography of major diatom 710 taxa in Southern Ocean sediments: 2. Open ocean related species. Palaeogeogr., 711 Palaeoclimatol., Palaeoecol., 223, 66-92.

712

713 De Baar, H.J.W., de Jong, J.T.M., Bakker, D.C.E. et al. (1995) Importance of iron for 714 phytoplankton blooms and carbon dioxide drawdown in the Southern Ocean. Nature $715 \quad 373,412-415$. 
717 Dunbar, R.B., Leventer, A.R. and Mucciarone, D.A. (1998) Water column sediment

718 fluxes in the Ross Sea, Antarctica: atmospheric and sea ice forcing. J. Geophys. Res.

$719103(30) 741-59$

720

721 Esper, O., Gersonde, R., Kadagies, N. (2010). Diatom distribution in southeastern Pacific

722 surface sediments and their relationship to modern environmental variables.

723 Palaeogeogr., Palaeoclimatol., Palaeoecol., 287, 1-27.

724

725 Fischer, G., Fütterer, D., Gersonde, R., et al. (1988) Seasonal variability of particle flux in 726 the Weddell Sea and its relation to ice cover. Nature, 335, 426-8.

727

728 Fischer, G., Gersonde, R., Wefer, G. (2002) Organic carbon, biogenic silica and diatom 729 fluxes in the marginal winter sea-ice zone and in the Polar Front Region: interannual 730 variations and differences in composition. Deep-Sea Res. (2 Top. Stud. Oceanogr.), 47, $731 \quad 1721-1745$.

732

733 Fitzwater, S.E. Johnson, K.S., Gordon, et al. (2000) Trace metal concentrations in the 734 Ross Sea and their relationship with nutrients and phytoplankton growth. Deep-Sea Res. 735 (2 Top. Stud. Oceanogr.), 47, 3159-3179.

736

737 Flores, J.A., Sierro, F.J. (1997) A revised technique for the calculation of calcareous 738 nannofossil accumulation rates. Micropal., 43, 321-324.

739

740 Gall, M.P., Boyd, P.W., Hall, J., et al. (2001) Phytoplankton processes. Part 1: 741 Community structure during the Southern Ocean Iron Release Experiment (SOIREE) 
744 Gardner, W.D. (1980) Sediment trap dynamics and calibration: a laboratory evaluation. J. 745 Mar. Res., 38, 17-39.

746

747 Gardner, W.D. (1985). The effect of tilt on sediment trap efficiency. Deep-Sea Res. (1 748 Oceanogr. Res. Pap.) 32, 349-361.

749

750 Gladstone, R.M., Bigg, G.R., Nicholls, K.W. (2001) Iceberg trajectory modelling and 751 meltwater injection in the Southern Ocean. J. Geophys Res., 106 (9), 19903-19915.

752

753 Goldman, J.C. (1993) Potential role of large oceanic diatoms in new primary production. 754 Deep-Sea Res. (1 Oceanogr. Res. Pap.) 40 (1), 159-168.

755

756 Goldman, J.C., McGillicuddy, D.J. (2003) Effect of large marine diatoms growing at 757 low light on episodic new production. Limnol. Oceanogra., 48 (3), 1176-1182.

758

759 Gomi, Y., Fukuchi, M., Taniguchi, A. (2010) Diatom assemblages at subsurface 760 chlorophyll maximum layer in the eastern Indian sector of the Southern Ocean in 761 summer. J. Plank. Res. 32 (7), 1039-1050.

762

763 Grigorov, I., Rigual-Hernandez, A.S., Honjo, S., et al. (2014) Settling fluxes of diatom 764 frustules to the interior of the Antarctic Circumpolar Current along $170^{\circ} \mathrm{W}$. Deep-Sea 765 Res. (1 Oceanogr. Res. Pap.), 93, 1-13. 
767 Hallegraeff, G.M. (1986) Taxonomy and morphology of the marine plankton diatoms 768 Thalassionema and Thalassiothrix. Diatom Research, 1, 57-80.

769

770 Hart, T. (1934) On the phytoplankton of the South-West Atlantic and the Bellinghausen 771 Sea, 1929-31. Discovery Reports, 8, 1-268.

772

773 Heussner, S., Durrieu De Madron, X., Calafat, A. et al. (2006) Spatial and temporal 774 variability of downward particle fluxes on a continental slope: Lessons from an 8-yr experiment in the Gulf of Lions (NW Mediterranean) Mar. Geol., 234, 63-92.

776

777 Honjo, S. (1996) Fluxes of particles to the interior of the open oceans, in Particle Flux in 778 the Ocean, edited by V. Ittekkot et al., pp. 91-154, John Wiley, New York.

779

780 Honjo, S. (2009) Biological pump and particulate fluxes. In: Steele, J.H., Thorpe, S.A., 781 Turekian, K.K. (Eds.) Encyclopaedia of ocean sciences. Academic Press, San Diego, 782 CA, 371-375

783

784 Honjo, S., Doherty, K.W. (1988) Large aperture time-series sediment traps; design 785 objectives, construction and application. Deep-Sea Res. 35(1), 133-149

786

787 Honjo, S., Francois, R., Manganini, S., et al. (2000) Particle fluxes to the interior of the 788 Southern Ocean in the Western Pacific sector along 170 degrees W. Deep-Sea Res. (2 789 Top. Stud. Oceanogr.), 47 (15-16), 3521-3548. 
791 Honjo, S., Manganini, S.J., Krishfield, R.A. et al. (2008) Particulate organic carbon fluxes 792 to the ocean interior and factors controlling the biological pump: A synthesis of global 793 sediment trap programs since 1983. Progr. Ocean., 76 (3), 217-285.

794

795 Honjo, S., Spencer, D.W., Gardner, W.D. (1992) A sediment trap intercomparison 796 experiment in the Panama Basin, 1979. Deep-Sea Res. (1 Oceanogr. Res. Pap.) 39, 797 333-358.

798

799 Ichinomiya, M., Gomi, Y., Nakamachi, M., et al. (2008) Temporal variations in the 800 abundance and sinking flux of diatoms under fast ice in summer near Syowa Station, 801 East Antarctica. Polar Science, 2, 33-40.

802

803 Ishikawa, A., Wasiyama, N., Tanimura, A., et al. (2001) Variation in the diatom 804 community under fast ice near Syowa Station, Antarctica, during the austral summer of 805 1997/98. Polar Bioscience, 14, 10-23.

806

807 Johnson, K.S., Gordon, R.M. and Coale, K.H. (1997) What controls dissolved iron 808 concentrations in the world ocean?. Mar. Chem., 57 (3-4), 137-161.

809

810 Kemp, A.E.S., Pike, J., Pearce, R.B. et al. (2000) The "Fall dump" a new perspective on 811 the role of a "shade flora" in the annual cycle of diatom production and export flux. 812 Deep-Sea Res. (1 Oceanogr. Res. Pap.), 47, 2129-2154. 
814 Kemp, A.E.S., Pearce, R.B., Grigorov, I. (2006) Production of giant marine diatoms and 815 their export at oceanic frontal zones:implications for $\mathrm{Si}$ and $\mathrm{C}$ flux from stratified 816 oceans. Global Biogeochem. Cycles 20 (4), GB4S04.

817

818 Kemp, A.E.S., Villareal, T.A. (2013) High diatom production and export in stratified 819 waters - A potential negative feedback to global warming. Progr. Ocean., 119 (0), 482023.

821

822 Kimura, N., Wakatsuchi, M. (2011) Large-scale processes governing the seasonal 823 variability of Antarctic sea-ice area. Tellus 63A, 828-840.

824

825 Kopczynska, E.E., Dehairs, F., Elskens, M. et al. (2001) Phytoplankton and 826 microzooplankton variability between the Subtropical and Polar Fronts south of 827 Australia: Thriving under regenerative and new production in late summer. J. Geophys. $828 \quad$ Res., 106, 31597-31609.

829

830 Lam, P. J., Bishop, J.K.B. (2007) High biomass low export regimes in the southern ocean. Deep-Sea Res. (2 Top. Stud. Oceanogr.), 54 (5-7), 601-638

832

833 Lampitt, R.S., Antia, A.N. (1997) Particle flux in deep seas: regional characteristics and 834 temporal variability. Deep-Sea Res. (1 Oceanogr. Res. Pap.), 44 (8): 1377-1403.

835

836 Laubscher, R.K., Perissinotto, R. and McQuaid, C.D. (1993) Phytoplankton production 837 and biomass at frontal zones in the Atlantic Sector of the Southern Ocean. Polar Biol., 838 13, 471-481. 
840 Leventer, A., Dunbar, R.B. (1987) Diatom flux in McMurdo Sound, Antarctica. Mar. 841 Micropaleontol., 12, 49-64.

842

843 Leventer, A., Dunbar, R.B., DeMaster, D.J. (1993) Diatom Evidence for Late Holocene 844 Climatic Events in Granite Harbor, Antarctica. Paleoceanography 8, 373-386.

845

846 Leventer, A., Dunbar, R.B., (1996) Factors influencing the distribution of diatoms and 847 other algae in the Ross Sea. J. Geophys. Res., 101, 18489-500.

848

849 Locarnini, R.A., Mishonov, A.V. and Antonov, J.I. (2010) World Ocean Atlas 2009, 850 Volume 1: Temperature. Vol. 1, U.S. Government Printing Office, Washington, D.C. 851

852 Massom, R., Reid, P., Stammerjohn, S., et al. (2013) Change and Variability in East 853 Antarctic Sea Ice Seasonality, 1979/80-2009/10. Plos one 8 (5), e64756.

854

855 Martin, J.H., Fitzwater, S.E., Gordon, R. M. (1990) Iron deficiency limits phytoplankton 856 growth in Antarctic waters. Global Biogeochem. Cycles 4, 5-12.

857

858 Matsumoto K., Sarmiento J.L. and Brzezinski M.A. (2002) Silicic acid leakage from the 859 Southern Ocean: A possible explanation for glacial atmospheric pCO2. Global 860 Biogeochem. Cycles, 16, 1031.

861

862 Moore, J.K., Abbott, M.R. (2000) Phytoplankton chlorophyll distributions and primary 863 production in the Southern Ocean. J. Geophys. Res., 105, 28709-28722. 
865 Nelson, D.M., Tréguer, P., Brzezinski, M.A., et al. (1995) Production and dissolution of 866 biogenic silica in the ocean: Revised global estimates, comparison with regional data 867 and relationship to biogenic sedimentation. Global Biogeochem. Cycles, 9, 359-372.

868

869 Orsi, A.H., Whitworth III, T., Nowlin Jr., W.D. (1995) On the meridional extent and 870 fronts of the Antarctic Circumpolar Current. Deep-Sea Res. (1 Oceanogr. Res. Pap.), 42, 641-673.

872

873 Ortiz, J.D., Mix, A.C. (1997) Comparison of Imbrie-Kipp transfer function and modern 874 analog temperature estimates using sediment trap and core top foraminiferal faunas. 875 Paleoceanography, 12, 175-190.

876

877 Parslow, J., Boyd, P., Rintoul, S.R. et al. (2001) A sub-surface chlorophyll maximum in 878 the Polar Frontal Zone south of Australia: seasonal evolution and implications for 879 phytoplankton-light-nutrient interactions. J. Geophys. Res., 106, 31543-31550.

880

881 Pilskaln, C.H., Manganini, S.J., Trull, T., et al. (2004) Geochemical particle fluxes in the 882 Southern Indian Ocean seasonal ice zone: Prydz Bay region, east Antarctica. Deep-Sea 883 Res. (1 Oceanogr. Res. Pap.), 50, 307-32.

884

885 Pondaven, P., Ragueneau, O., Tréguer, P., et al. (2000) Resolving the `opal paradox' in 886 the Southern Ocean. Nature, 405, 168-172.

887 
888

889

890

891 Quéguiner, B. (2013) Iron fertilization and the structure of planktonic communities in 892 high nutrient regions of the Southern Ocean. Deep-Sea Res. (1 Oceanogr. Res. Pap.)I, $89390,43-54$.

894

895 Quilty, P., Kerry, K.R., Marchant, H.J. (1985) A seasonally recurrent patch of Antarctic 896

897

898

899

900

901 Rintoul, S.R., Bullister, J.L. (1999) A late winter Hydrographic section from Tasmania to 902 903

904 905

906

907

908

909

910

911

Popp, B.N., Trull, T., Kenig, F. et al. (1999) Controls on the carbon isotopic composition of Southern Ocean phytoplankton. Global Biogeochem. Cycles 13 (4), 827-843. planktonic diatoms. Search (ANZAAS), 16, 48.

Reynolds, R.W., Rayner, N.A., Smith, T.M. et al. (2002) An improved in situ and satellite SST analysis for climate. J. Climate, 15, 1609-1625. Antarctica. Deep-Sea Res. (1 Oceanogr. Res. Pap.), 46, 1417-1454.

Rintoul, S.R., Sokolov, S. (2001) Baroclinic transport variability of the Antarctic Circumpolar Current south of Australia (WOCE repeat section SR3). J. Geophys. Res. 106, 2795-2814.

Romero, O., Armand, L.K., Crosta, X. et al. (2005) The biogeography of major diatom taxa in Southern Ocean sediments: 3. Tropical/Subtropical species. Palaeogeogr., Palaeoclimatol., Palaeoecol., 223, 49-65. 
912 Romero, O.E., Fischer, G., Lange, C.B. et al.(2000) Siliceous phytoplankton of the 913 western equatorial Atlantic: sediment traps and surface sediments. Deep-Sea Res. (2 914 Top. Stud. Oceanogr.) 47, 1939-1959.

915

916 Romero, O.E., Lange, C.B., Fischer, et al. (1999). Variability in export production

917 documented by downward fluxes and species composition of marine planktonic 918 diatoms: observations from the tropical and equatorial Atlantic. In: Fischer, G., Wefer, 919 G. (Eds.), The Use of Proxies in Paleoceanography, Examples from the South Atlantic. 920 Springer, Berlin, Heidelberg, pp. 365-392.

921

922 Romero, O., Thunell, R.C., Astor, Y., et al. (2009) Seasonal and interanual dynamics in 923 diatom production in the Cariaco Basin, Venezuela. Deep-Sea Res. (1 Oceanogr. Res. 924 Pap.), 56, 571-581.

925

926 Sakshaug, E., Holm-Hansen, O. (1984) Factors governing pelagic production in polar 927 oceans. In: Holm-Hansen, O., Bolis, L., Gilles, R. (Eds.), Marine Phytoplankton and 928 Productivity. Lecture Notes on Coastal and Estuarine Studies, vol. 8. Springer, Berlin, 929 pp. 1-18.

930

931 Sancetta, C., Calvert, S.E. (1988) The annual cycle of sedimentation in Saanich Inlet, 932 British Columbia: implications for the interpretation of diatom fossil assemblages. Deep $933 \quad$ Sea Res. 35 (1), 71-90

935 Sarmiento, J.L., T.M.C. Hughes, R.J. Stouffer et al. (1998) Simulated response of the 936 ocean carbon cycle to anthropogenic climate warming, Nature, 393, 245-249. 
938 Schrader, H. J., Gersonde, R. (1978) Diatoms and silicofagellates. Micropaleontological 939 counting methods and techniques: an exercise on an eight metres section of the Lower 940 Pliocene of Capo Rosello, Sicily. Utrecht Bull. Micropaleontol. 17, 129-176.

941

942 Semina, H.J. (2003) SEM-studied diatoms of different regions of the World Ocean. 943 Iconographia Diatomologica 10, 1- 362.

944

945 Smetacek, V. (1985) Role of sinking in diatom life-history cycles: ecological, 946 evolutionary and geological significance. Mar. Biol. 84, 239-251.

947

948 Smetacek, V. (1999). Diatoms and the ocean carbon cycle. Protist, 250, 25- 32

949

950 Smetacek, V., Assmy, P., Henjes, J. (2004) The role of grazing in structuring Southern

951 Ocean pelagic ecosystems and biogeochemical cycles. Antarctic Science, 16: 541-558.

952

953 Smith Jr., W.O., Nelson, D.M. (1986) Importance of ice edge phytoplankton production 954 in the Southern Ocean. Bioscience 36 (4), 251-257.

955

956 Smith Jr., K.L., Sherman, A.D., Shaw, T.J. et al. (2011) Carbon export associated with 957 free-drifting icebergs in the Southern Ocean. Deep-Sea Res. (2 Top. Stud. Oceanogr.) 958 58, (11-12), 1485-1496.

959

960 Sohrin, Y., Iwamoto, S., Matsui, M. et al. (2000) The distribution of Fe in the Australian 961 sector of the Southern Ocean. Deep-Sea Res. (1 Oceanogr. Res. Pap.), 47, 55-84. 
963 Sokolov, S., Rintoul, S.R. (2002) Structure of southern ocean fronts at 140 E. J. Mar. 964 Syst. 37, 151-184.

965

966 Sokolov, S., Rintoul, S.R. (2007) Multiple Jets of the Antarctic Circumpolar Current 967 South of Australia. J. Physical Oceanogr., 37, 1394-1412

968

969 Sokolov, S., Rintoul, S.R. (2009a) Circulation structure and distribution of the Antarctic 970 Circumpolar Current fronts: 1. Mean circumpolar paths. J. Geophys. Res. 114, C11018.

971

972 Sokolov, S., Rintoul, S.R. (2009b) Circulation structure and distribution of the Antarctic 973 Circumpolar Current fronts: 2. Variability and relationship to sea surface height. J. 974 Geophys. Res. 114, C11019.

975

976 Sullivan, C.W., McClain, C.R., Comiso, J.C., Smith, W.O. (1988) Phytoplankton standing 977 crops within an Antarctic ice edge assessed by satellite remote sensing. J. Geophys. Res. 978 93, 12487-12498.

979

980 Suzuki, H., Sasaki, H., Fukuchi, M. (2001) Short-term variability in the flux of rapidly 981 sinking particles in the Antarctic Marginal Ice Zone. Polar Biol. 24, 697-705.

982

983 Takahashi, K. (1986) Seasonal fluxes of pelagic diatoms in the subarctic Pacific, 1982984 1983. Deep-Sea Res. 33, 1225-51.

985 
986 Taylor, F., Sjunneskog, C. (2002) Postglacial marine diatom record of the Palmer Deep, 987 Antarctic Peninsula (ODP Leg 178, Site 1098) 2. Diatom assemblages. 988 Paleoceanography 17, PAL 2-1-PAL 2-12.

989

990 Tréguer, P. J., De La Rocha, C. L. (2013) The world ocean silica cycle. Annual review of 991 marine science, 5, 477-501.

992

993 Trull, T., Armand, L. (2001) Insights into Southern Ocean Carbon export from the $\delta 13$ C 994 of particles and dissolved inorganic carbon during the SOIREE iron release experiment. 995 Deep-Sea Res. (2 Top. Stud. Oceanogr.), 48, 2655-2680.

996

997 Trull, T., SedwickF, P.N., Griffiths, F.B. et al. (2001a) Introduction to special section: 998 SAZ Project. J. Geophys. Res., 106, 31425-31429.

999

1000 Trull, T., Bray, S., Manganini, S., et al. (2001b) Moored sediment trap measurements of 1001 carbon export in the Subantarctic and Polar Frontal Zones of the Southern Ocean, south 1002 of Australia, J. Geophys. Res., 106, 31489-31510.

1003

1004 Trull, T., Rintoul, S. R., Hadfield, M., et al. (2001) Circulation and seasonal evolution of 1005 polar waters south of Australia: Implications for iron fertilization of the Southern 1006 Ocean, Deep-Sea Res. (1 Oceanogr. Res. Pap.), 48, 2439-2466

1007

1008 Varela, D.E., Pride, C.J., Brzezinski, M.A. (2004) Biological fractionation of silicon 1009 isotopes in Southern Ocean surface waters. Global Biogeochem. Cy., 18, GB1047. 
1011 Wefer, G., Fischer, G., F. Utterer, D. et al. (1988) Seasonal particle flux in the Bransfield 1012 Strait, Antarctica. Deep-Sea Res. (1 Oceanogr. Res. Pap.) 35 (6), 891-898.

1013

1014 Yu, E.F., Francois, R., Bacon, M.P. et al. (2001) Trapping efficiency of bottom-tethered 1015 sediment traps estimated from the intercepted fluxes of ${ }^{230} \mathrm{Th}$ and ${ }^{231} \mathrm{~Pa}$ Deep-Sea Res. 1016 (1 Oceanogr. Res. Pap.), 48 (3) 865-889.

1017

1018 Zeldis, J. (2001) Mesozooplankton community composition, feeding, and export 1019 production during SOIREE. Deep-Sea Res. (2 Top. Stud. Oceanogr.), 48, 2615-2634. 


\begin{tabular}{|c|c|c|c|c|c|c|c|c|c|c|c|}
\hline $61 \_2000$ & Sampling period & Length & Total Mass Flux & $\mathrm{BS}$ & & $\mathrm{Ca}$ & & $\mathrm{P}$ & & $\mathrm{POC} / \mathrm{PN}$ & Diatoms \\
\hline Cup & mid point & days & $\mathrm{mg} \mathrm{m}^{-2} \mathrm{~d}^{-1}$ & $\mathrm{mg} \mathrm{m}^{-2} \mathrm{~d}^{-1}$ & $\%$ & $\mathrm{mg} \mathrm{m}^{-2} \mathrm{~d}^{-1}$ & $\%$ & $\mathrm{mg} \mathrm{m}^{-2} \mathrm{~d}^{-1}$ & $\%$ & molar ratio & $10^{6}$ valves $\mathrm{m}^{-2} \mathrm{~d}^{-1}$ \\
\hline 1 & Nov. 30, 2001 & 8 & 48 & 26 & 54 & 14 & 30 & 0.7 & 1.5 & 6.6 & - \\
\hline 2 & Dec. 08, 2001 & 8 & 78 & 47 & 61 & 17 & 22 & 1.7 & 2.2 & 6.1 & 9 \\
\hline 3 & Dec. 16, 2001 & 8 & 326 & 198 & 61 & 62 & 19 & 6.9 & 2.1 & 5.4 & 82 \\
\hline 4 & Dec. 24,2001 & 8 & 509 & 326 & 64 & 140 & 28 & 6.4 & 1.3 & 3.5 & 85 \\
\hline 5 & Jan. 01, 2002 & 8 & 1151 & 856 & 74 & 44 & 4 & 26.9 & 2.3 & 7.4 & 408 \\
\hline 6 & Jan. 09, 2002 & 8 & 1069 & 796 & 75 & 170 & 16 & 14.8 & 1.4 & 4.9 & 200 \\
\hline 7 & Jan. 17, 2002 & 8 & 656 & 478 & 73 & 60 & 9 & 11.3 & 1.7 & 6.1 & 159 \\
\hline 8 & Jan. 25, 2002 & 8 & 702 & 541 & 77 & 38 & 5 & 11.0 & 1.6 & 6.1 & 296 \\
\hline 9 & Feb. 02, 2002 & 8 & 666 & 520 & 78 & 39 & 6 & 12.0 & 1.8 & 6.5 & 184 \\
\hline 10 & Feb. 10, 2002 & 8 & 595 & 469 & 79 & 24 & 4 & 8.2 & 1.4 & 6.2 & 295 \\
\hline 11 & Feb. 18, 2002 & 8 & 534 & 425 & 80 & 20 & 4 & 6.2 & 1.2 & 6.5 & 149 \\
\hline 12 & Feb. 26, 2002 & 8 & 524 & 418 & 80 & 19 & 4 & 4.7 & 0.9 & 6.5 & 152 \\
\hline 13 & Mar. 06, 2002 & 8 & 586 & 471 & 80 & 15 & 3 & 6.9 & 1.2 & 7.2 & 120 \\
\hline 14 & Mar. 14, 2002 & 8 & 285 & 230 & 81 & 11 & 4 & 3.2 & 1.1 & 6.6 & 71 \\
\hline 15 & Mar. 22, 2002 & 8 & 290 & 253 & 87 & 7 & 3 & 3.2 & 1.1 & 6.8 & 66 \\
\hline 16 & Mar. 30, 2002 & 8 & 263 & 218 & 83 & 8 & 3 & 2.6 & 1.0 & 6.1 & 87 \\
\hline 17 & Apr. 08, 2002 & 10 & 264 & 220 & 83 & 7 & 3 & 2.2 & 0.8 & 6.4 & 97 \\
\hline 18 & Мay. 08, 2002 & 50 & 130 & 102 & 78 & 5 & 4 & 1.2 & 1.0 & 5.9 & 47 \\
\hline 19 & Jun. 29, 2002 & 54 & 65 & 52 & 79 & 2 & 4 & 0.7 & 1.0 & 6.6 & 10 \\
\hline 20 & Aug. 22, 2002 & 55 & 56 & 44 & 78 & 2 & 4 & 0.8 & 1.5 & 6.6 & 19 \\
\hline 21 & Sep. 29, 2002 & 20 & 42 & 34 & 81 & 2 & 4 & 0.5 & 1.3 & 7.2 & 6 \\
\hline Annualised values & & & 232 & 178 & 76 & 17 & 7.4 & 3.3 & 1.4 & 6.1 & 67 \\
\hline
\end{tabular}

\begin{tabular}{|c|c|c|c|c|c|c|c|c|c|c|c|}
\hline $61 \_3700$ & Sampling period & Length & Total Mass Flux & \multicolumn{2}{|c|}{$\mathrm{BSiO}_{2}$} & \multicolumn{2}{|c|}{$\mathrm{CaCO}_{3}$} & \multicolumn{2}{|c|}{ POC } & \multirow{2}{*}{$\begin{array}{l}\mathrm{POC} / \mathrm{PN} \\
\text { molar ratio }\end{array}$} & \multirow{2}{*}{$\begin{array}{c}\text { Diatoms } \\
10^{6} \text { valves } \mathrm{m}^{-2} \mathrm{~d}^{-1}\end{array}$} \\
\hline Cup & mid point & days & $\mathrm{mg} \mathrm{m}^{-2} \mathrm{~d}^{-1}$ & $\mathrm{mg} \mathrm{m}^{-2} \mathrm{~d}^{-1}$ & $\%$ & $\mathrm{mg} \mathrm{m}^{-2} \mathrm{~d}^{-1}$ & $\%$ & $\mathrm{mg} \mathrm{m}^{-2} \mathrm{~d}^{-1}$ & $\%$ & & \\
\hline 1 & Nov. 30, 2001 & 8 & 38 & 25 & 64 & 9 & 23 & 0.4 & 1.1 & 7.4 & - \\
\hline 2 & Dec. 08, 2001 & 8 & 31 & 17 & 54 & 9 & 28 & 0.4 & 1.2 & 6.4 & - \\
\hline 3 & Dec. 16, 2001 & 8 & 99 & 51 & 52 & 29 & 30 & 1.4 & 1.4 & 6.7 & 4 \\
\hline 4 & Dec. 24,2001 & 8 & 231 & 148 & 64 & 59 & 26 & 1.4 & 0.6 & 2.6 & 12 \\
\hline 5 & Jan. 01, 2002 & 8 & 873 & 656 & 75 & 87 & 10 & 17.3 & 2.0 & 6.8 & 118 \\
\hline 6 & Jan. 09, 2002 & 8 & 1157 & 886 & 77 & 154 & 13 & 19.8 & 1.7 & 6.9 & 479 \\
\hline 7 & Jan. 17, 2002 & 8 & 828 & 611 & 74 & 166 & 20 & 9.4 & 1.1 & 4.6 & 354 \\
\hline 8 & Jan. 25, 2002 & 8 & 490 & 376 & 77 & 34 & 7 & 6.4 & 1.3 & 6.4 & 169 \\
\hline 9 & Feb. 02, 2002 & 8 & 491 & 384 & 78 & 32 & 6 & 6.5 & 1.3 & 6.1 & 385 \\
\hline 10 & Feb. 10, 2002 & 8 & 419 & 335 & 80 & 19 & 4 & 6.0 & 1.4 & 7.0 & 281 \\
\hline 11 & Feb. 18, 2002 & 8 & 584 & 475 & 81 & 36 & 6 & 6.2 & 1.1 & 6.2 & 254 \\
\hline 12 & Feb. 26, 2002 & 8 & 581 & 473 & 81 & 31 & 5 & 5.2 & 0.9 & 5.5 & 238 \\
\hline 13 & Mar. 06, 2002 & 8 & 849 & 737 & 87 & 23 & 3 & 7.6 & 0.9 & 6.5 & 326 \\
\hline 14 & Mar. 14, 2002 & 8 & 369 & 233 & 63 & 18 & 5 & 3.3 & 0.9 & 6.5 & 44 \\
\hline 15 & Mar. 22, 2002 & 8 & 218 & 174 & 80 & 8 & 4 & 2.6 & 1.2 & 7.3 & 32 \\
\hline 16 & Mar. 30, 2002 & 8 & 258 & 198 & 77 & 10 & 4 & 2.5 & 1.0 & 7.2 & 43 \\
\hline 17 & Apr. 08, 2002 & 10 & 257 & 202 & 79 & 9 & 3 & 2.3 & 0.9 & 6.9 & 32 \\
\hline 18 & May. 08, 2002 & 50 & 118 & 98 & 83 & 5 & 4 & 1.2 & 1.0 & 6.3 & 8 \\
\hline 19 & Jun. 29, 2002 & 54 & 0 & 0 & 83 & 0 & 4 & 0.0 & 1.0 & 6.3 & - \\
\hline 20 & Aug. 22, 2002 & 55 & 0 & 0 & 83 & 0 & 4 & 0.0 & 1.0 & 6.3 & - \\
\hline 21 & Sep. 29, 2002 & 20 & 0 & 0 & 83 & 0 & 4 & 0.0 & 1.0 & 6.3 & - \\
\hline Annualised values & & & 188 & 146 & 78 & 17 & 9 & 2.3 & 1.2 & 6.2 & 62 \\
\hline Annual flux & & & $69 \mathrm{~g} \mathrm{~m}^{-2} \mathrm{y}^{-1}$ & $53 \mathrm{~g} \mathrm{~m}^{-2} \mathrm{y}^{-1}$ & & $6 \mathrm{~g} \mathrm{~m}^{-2} \mathrm{y}^{-1}$ & & $0.9 \mathrm{~g} \mathrm{~m}^{-2} \mathrm{y}^{-1}$ & & & $2310^{9}$ valves $\mathrm{m}^{-2} \mathrm{y}^{-1}$ \\
\hline
\end{tabular}




\begin{tabular}{|c|c|c|c|c|}
\hline $2000 \mathrm{~m}$ & Total Mass Flux & $\mathrm{BSiO}_{2}$ & $\mathrm{CaCO}_{3}$ & POC \\
\hline Total Mass Flux & - & & & \\
\hline $\mathrm{BSiO}_{2}$ & 0.99 & - & & \\
\hline $\mathrm{CaCO}_{3}$ & 0.37 & 0.30 & - & \\
\hline $\mathrm{POC}$ & 0.86 & 0.83 & 0.24 & - \\
\hline $3700 \mathrm{~m}$ & Total Mass Flux & $\mathrm{BSiO}_{2}$ & $\mathrm{CaCO}_{3}$ & $\mathrm{POC}$ \\
\hline Total Mass Flux & - & & & \\
\hline $\mathrm{BSiO}_{2}$ & 0.99 & - & & \\
\hline $\mathrm{CaCO}_{3}$ & 0.61 & 0.54 & - & \\
\hline $\mathrm{POC}$ & 0.87 & 0.83 & 0.63 & - \\
\hline
\end{tabular}

Table 2 


\section{Table(s)}

\section{Click here to download Table(s): Table 3,eps}

Actinocyclus spp.

Actinocyclus actinochilus (Ehrenberg) Simonsen

Asteromphalus hookeri Ehrenberg

A. hyalinus Karsten

A. parvulus Karsten

Asteromphalus spp.

Azpeitia tabularis (Grunow) Fryxell et Sims

Chaetoceros aequatorialis var. antarcticus Manguin

Ch. atlanticus Cleve

Ch. dichaeta Ehrenberg

Ch. peruvianus Brightwell

Chaetoceros sp. A

Chaetoceros sp. B

Chaetoceros spp.

Chaetoceros Hyalochaete resting spores

Corethron spp.

Dactyliosolen antarcticus Castracane

Eucampia antarctica (Castracane) Mangin

Fragilariopsis curta (Van Heurck) Hustedt

F. cylindrus (Grunow) Krieger

F. kerguelensis (O’Meara) Hustedt

F. obliquecostata (van Heurck) Heiden

F. pseudonana (Hasle) Hasle

F. rhombica (O'Meara) Hustedt

F. ritscheri Hustedt

F. separanda Hustedt

F. cf. sublineata (Van Heurck) Heiden

Haslea trompii (Cleve) Simonsen

Navicula directa (Smith) Ralfs in Pritchard

N. sicula var. bicuneata (Castracane) Grunow

Pleurosigma directum Grunow in Van Heurck

Pseudo-nitzschia $<3 \mu \mathrm{m}$ transapical axis

$P$-n. heimii Manguin

Pseudo-nitzschia spp.

Porosira pseudodenticulata (Hustedt) Jousé

Proboscia spp.

Rhizosolenia antennata (Ehrenberg) Brown f. semispina Sundström

Rhizosolenia bergonii Peragallo

Rhizosolenia sp. f. 1A (Armand et Zielinski)

Rhizosolenia spp.

Thalassionema nitzschioides f. capitulata (Castracane) Moreno-Ruiz

T. nitzschioides f. lanceolata (Grunow) Pergallo et Pergallo

Stellarima stellaris (Roper) Hasle et Sims

Thalassiosira gravida Cleve

T. gracilis var. gracilis (Karsten) Hustedt

T. gracilis var. expecta (Van Landingham) Frxyell et Hasle

T. lentiginosa (Janisch) Fryxell

T. maculata Fryxell et Johansen

T. oestrupii (Ostenfeld) Hasle

T. oliveriana (O'Meara) Makarova et Nikolaev

T. tumida (Janisch) Hasle

T. leptopus (Grunow ex Van Heurck) Hasle et G.Fryxell

T. lineata Jousé

Thalassiosira spp. $<20 \mu \mathrm{m}$

Thalassiosira spp. $>20 \mu \mathrm{m}$

Thalassiosira sp. A

Thalassiosira sp. B

Thalassiothrix antarctica Schimper ex Karsten

Tropidoneis group

Other centrics

Other pennates
Average 309 days Average 172 days

0.03

0.02

0.01

0.20

0.26

0.32

0.01

0.57

0.03

0.29

0.19

0.00

0.14

0.13

0.27

0.25

0.01

0.14

1.00

0.29

72.41

0.03

3.64

1.58

0.13

2.85

0.04

0.01

0.58

0.10

0.03

0.72

0.02

0.19

0.03

0.00

0.00

0.00

0.01

0.07

0.09

0.02

0.00

0.05

6.08

0.65

4.63

0.02

0.02

0.37

0.07

0.01

0.14

0.62

0.05

0.22

0.03

0.18

0.05

0.07

0.01
0.00

0.48

0.29

0.35

0.01

0.74

0.06

0.37

0.16

0.01

0.11

0.19

0.32

0.14

0.00

0.20

1.11

0.10

68.34

0.05

1.43

2.13

0.11

2.03

0.03

0.02

1.06

0.14

0.03

1.41

0.02

0.08

0.03

0.01

0.02

0.02

0.02

0.02

0.11

0.02

0.02

0.11

7.41

1.30

6.77

0.02

0.01

0.42

0.10

0.54

0.36

0.29

0.00

0.01

0.08

0.58

0.12

0.02

0.01 

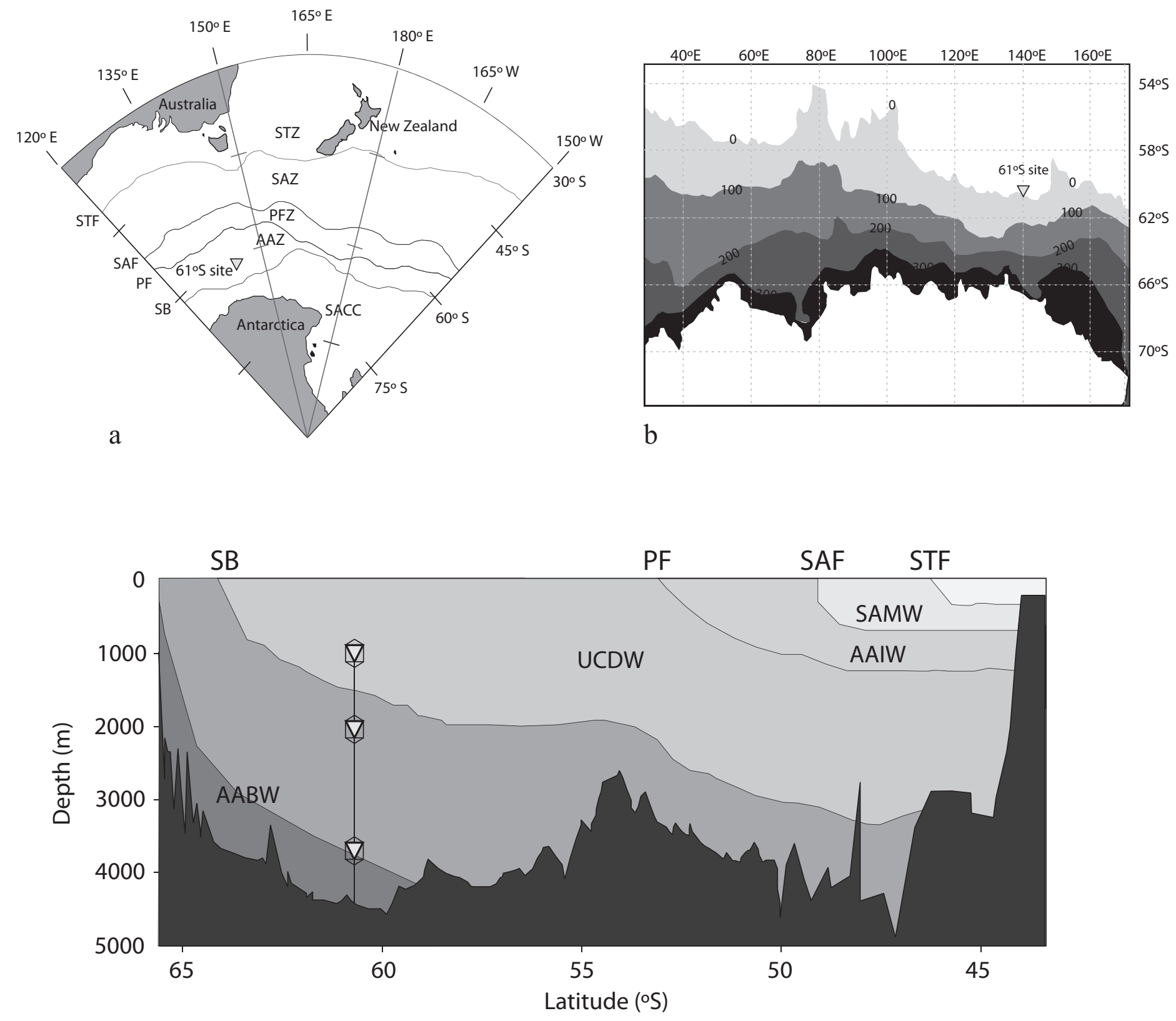

c

Figure 1 
Click here to download Figure(s): Fig. 1. Colour.eps
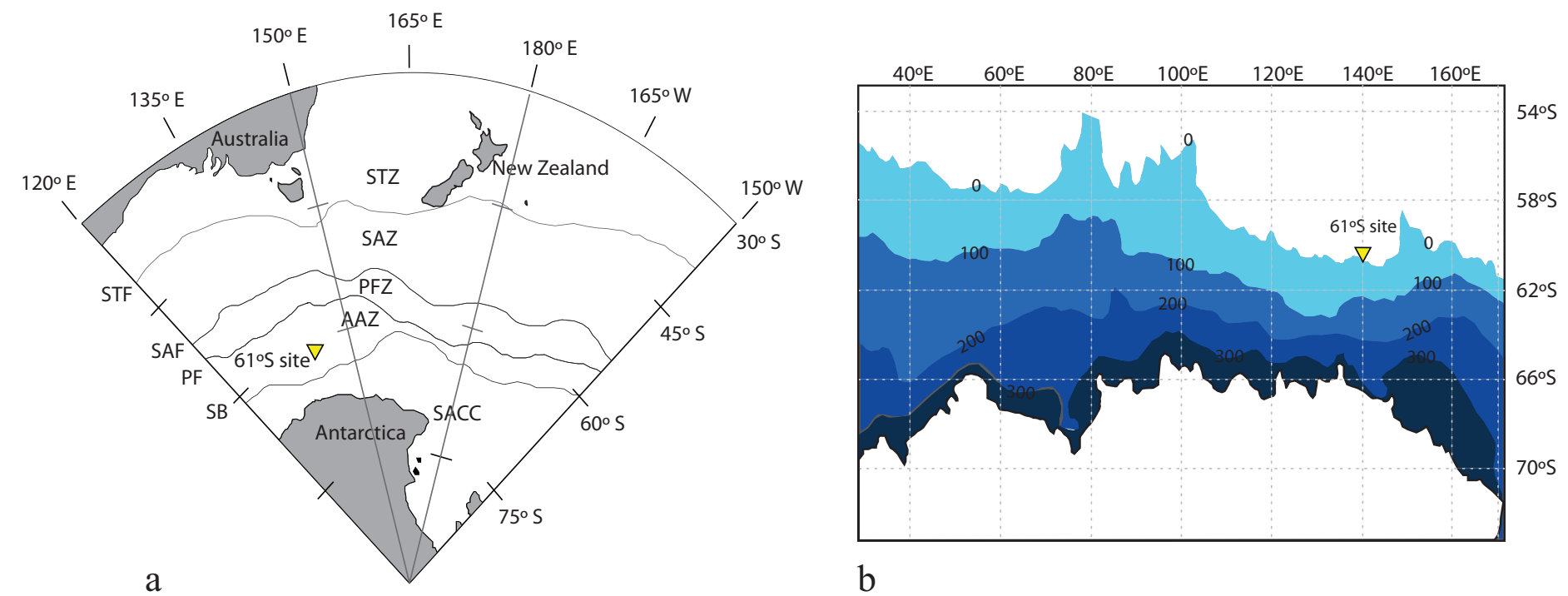

b

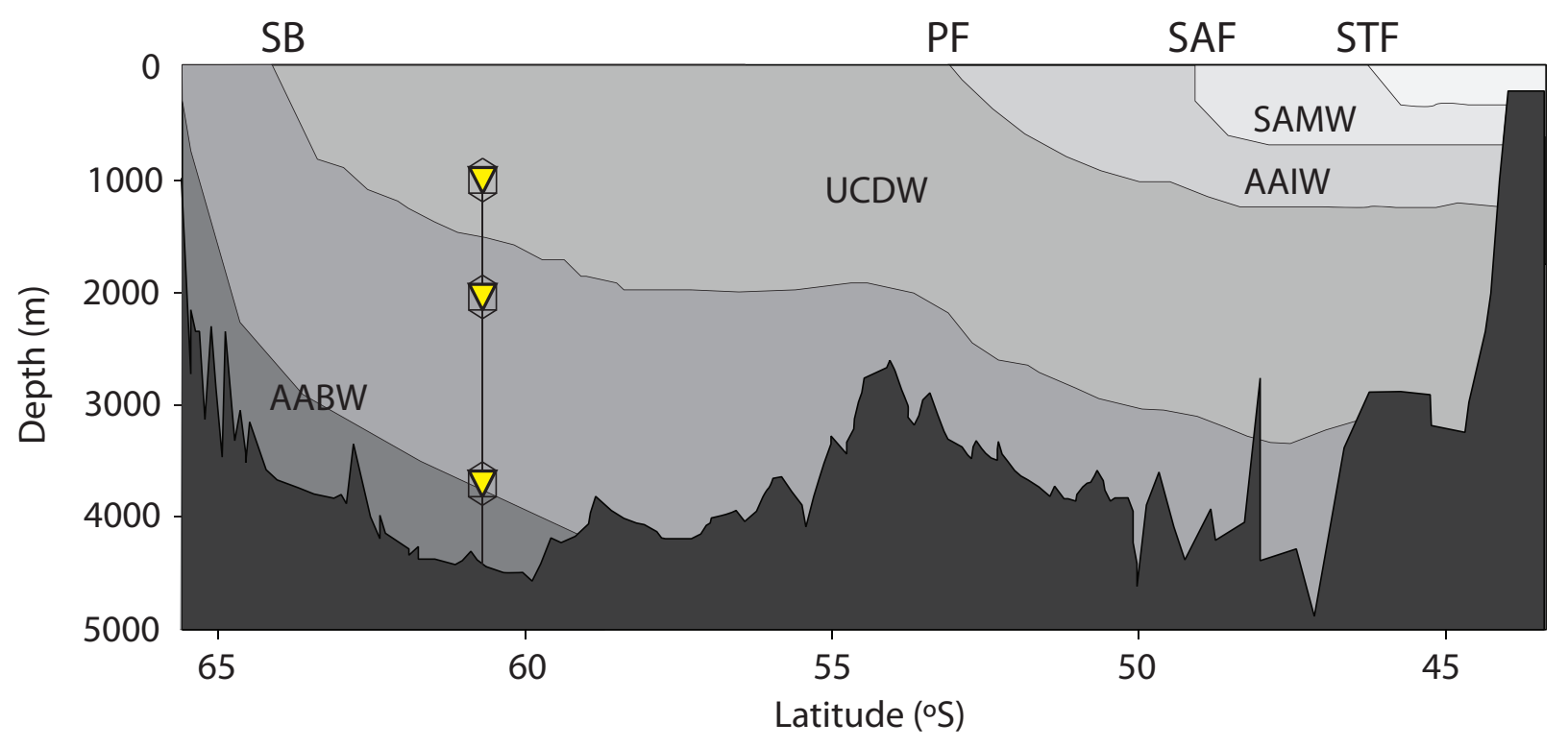

c

Figure 1 

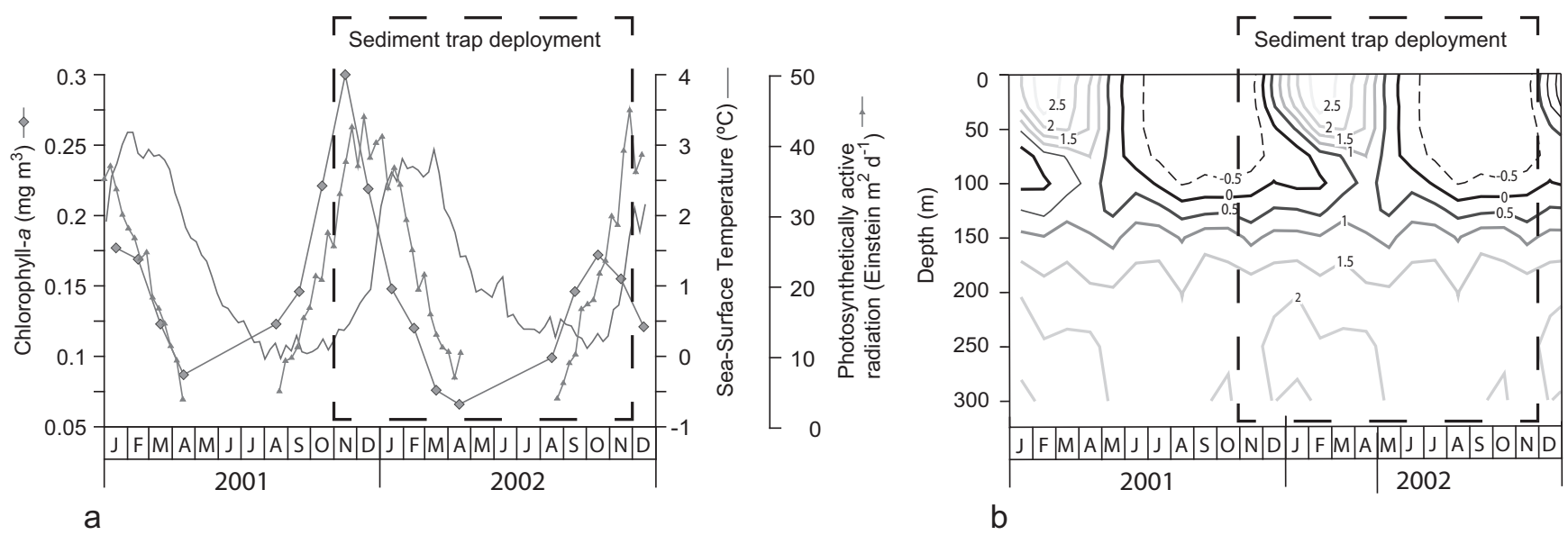

Figure 2 

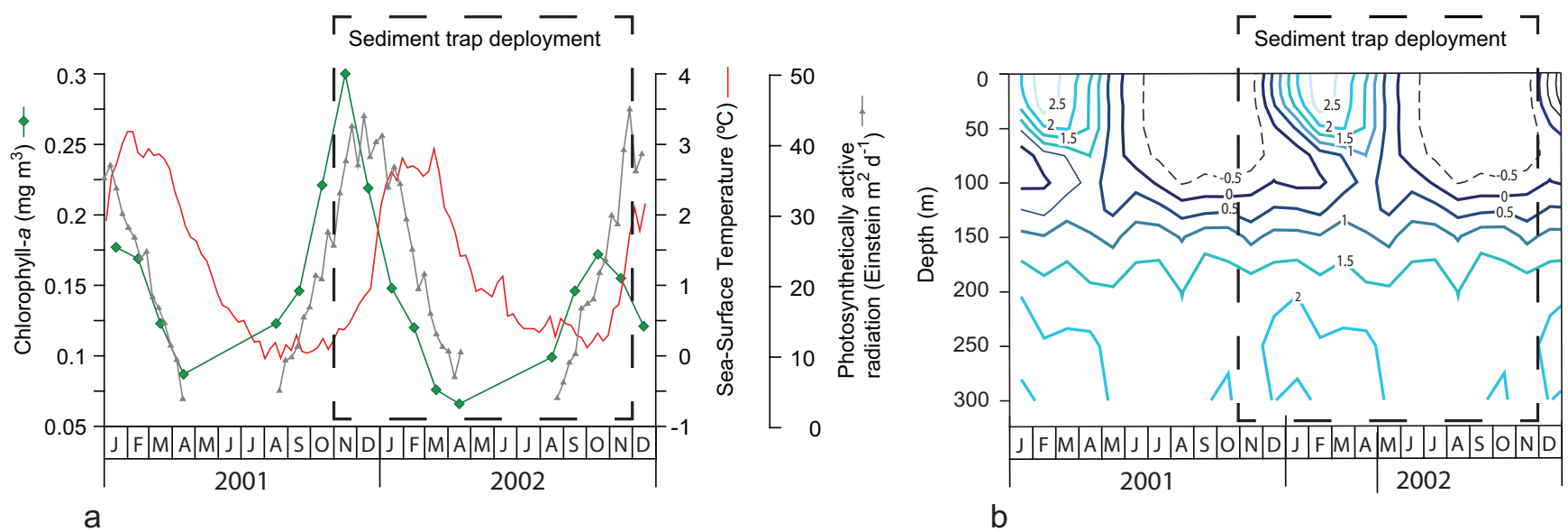

Figure 2 


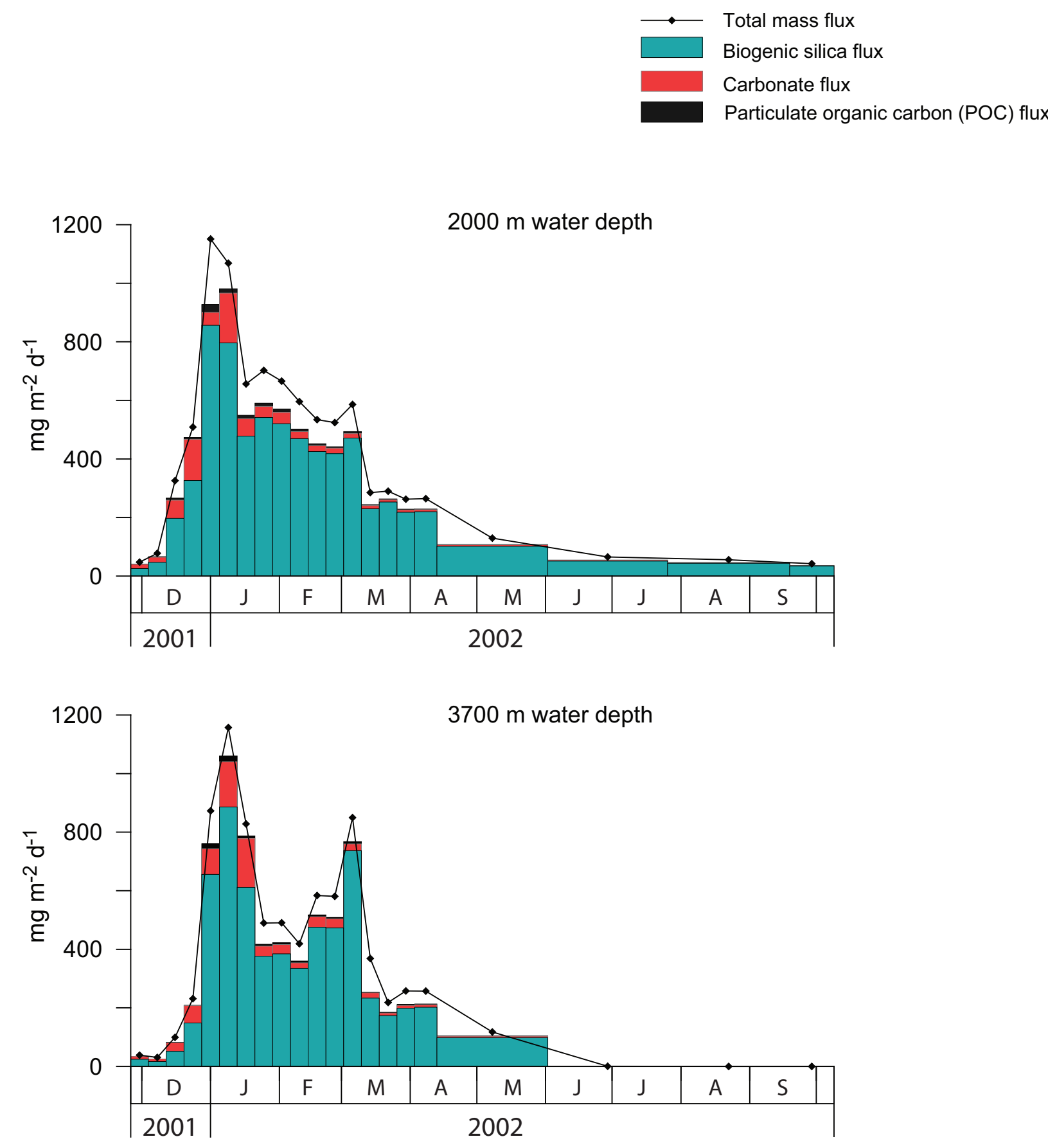

Figure 3 

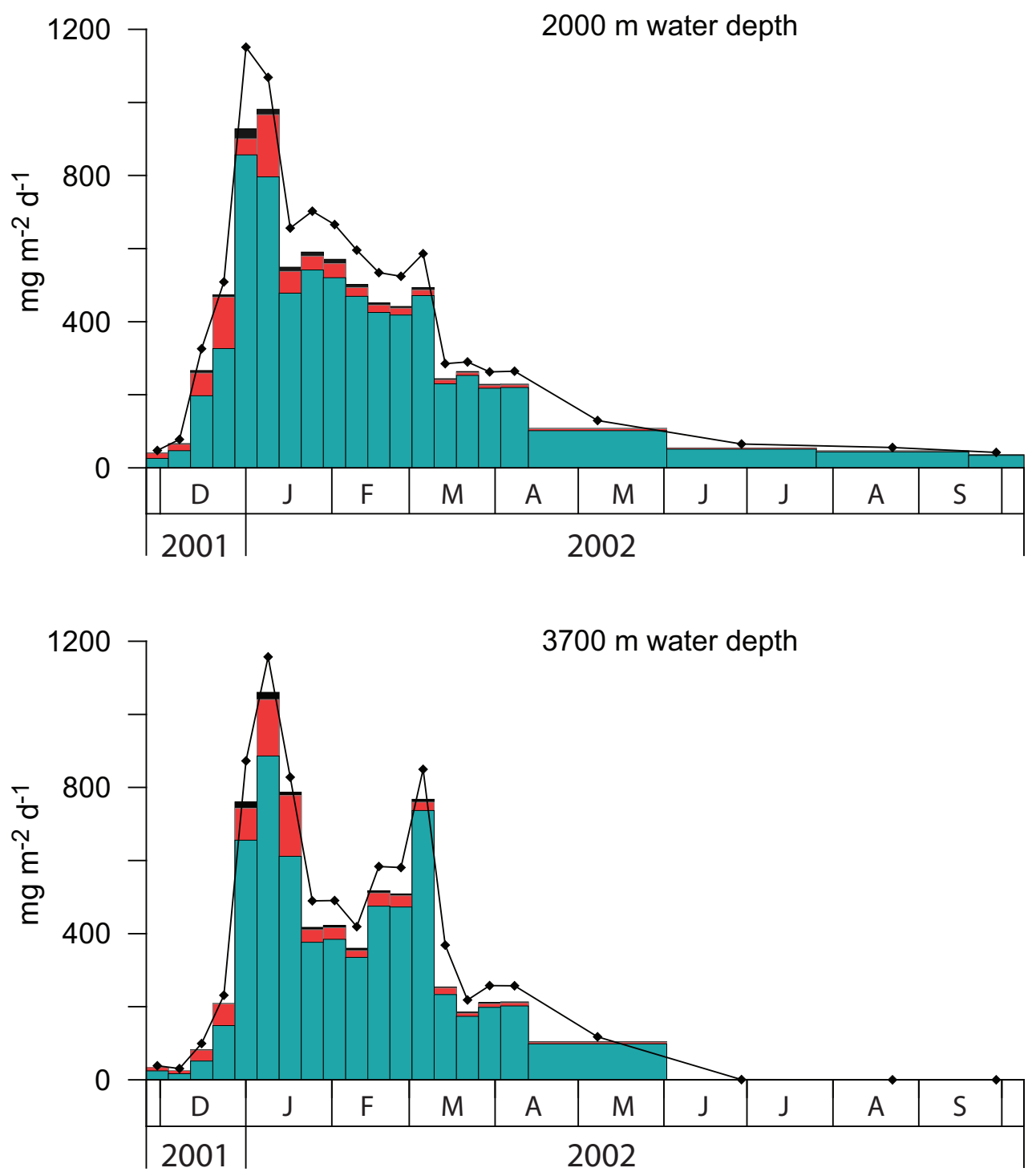

Figure 3 

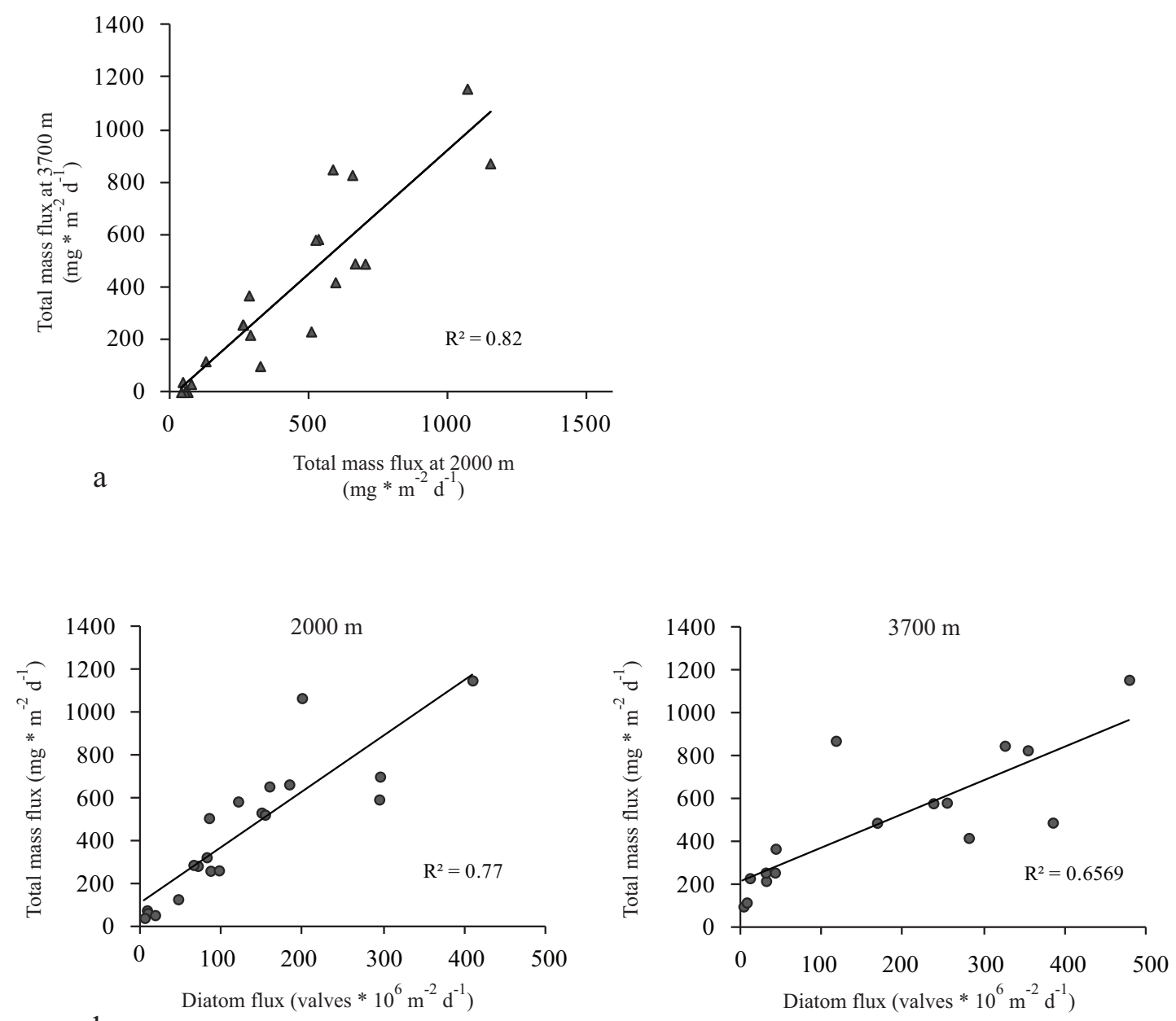

Figure 4 
